\title{
Synthesis of Stable, High-SOMO Zwitterionic Radicals: Enabling Intermolecular Electron Transfer between Naphthalenediimides
}

Jyoti Shukla, Sharvan Kumar, Rustam and Pritam Mukhopadhyay*

Supramolecular and Material Chemistry Lab, School of Physical Sciences, Jawaharlal Nehru University, New Delhi-110067, India.

\section{Supporting Information \\ Contents}

S. No. Topic

Page No.

1. Experimental section

2. Chart S1: Molecular structures of newly synthesized compounds

3. Synthesis and Characterization

4. Figure S1: Absorption spectra of $\mathbf{5}^{+} \mathbf{B r}^{-}$and $\mathbf{5}^{\cdot \pm}$

5. Figure S2: Determination of stability of $\mathbf{4}^{\cdot \pm}$ in solution

6. Figure S3: ESR spectra of zwitterionic radicals $\left(\mathbf{1}^{\cdot \pm}, \mathbf{4}^{\cdot \pm}\right.$ and $\left.\mathbf{5}^{\cdot \pm}\right)$

7. Figure S4-S6: Single crystal X-ray structures of $\mathbf{1}^{+} \mathbf{B r} \mathbf{r}^{-}$and $\mathbf{1}^{\cdot \pm}$ and self-assembly

8. Table S1: Selected bond lengths, angles and torsion angles of the crystals

9. Figure S7a: Cyclic Voltammograms of $\mathbf{1}^{+} \mathbf{B r}^{-}, \mathbf{4}^{+} \mathbf{B r}^{-}, \mathbf{5}^{+} \mathbf{B r}^{-}$and $\mathbf{1}^{\cdot \pm}, \mathbf{4}^{\cdot \pm}, \mathbf{5}^{\cdot \pm}$

10. Table S2: Electrochemical data of compounds $\mathbf{1}^{+} \mathbf{B r}^{-}, 4^{+} \mathbf{B r}^{-}$and $\mathbf{5}^{+} \mathbf{B r}^{-}$

11. Figure S7b: Cyclic Voltammograms of TMPDA and TTF

12. Table S3: Electrochemical data of $\mathbf{1}^{\cdot \pm}, \mathbf{4}^{\cdot \pm}, \mathbf{5}^{\cdot \pm}$ and TMPDA and TTF

13. Figure S8a-b: Optimized structures of $\mathbf{4}^{+}$and $\mathbf{4}^{\cdot \pm}$ and their frontier orbital diagrams and spin density plot of $\mathbf{4}^{\cdot \pm}$

14. Figures S9: UV-vis-NIR spectra of the electron transfer reaction of $\mathbf{1}^{\cdot \pm}$ with TCNQ

15. Figure S10-S11: FT-IR spectra of the compounds

16. Figure S12-S19: Mass Spectra of the compounds

17. Figure S20-S30: ${ }^{1} \mathrm{H},{ }^{13} \mathrm{C}, \mathrm{APT}$ and DEPT-135, ${ }^{31} \mathrm{P}$ NMR spectra

18. Table S4: Crystal data and structure refinement parameters

19. Table S5-S6: Coordinates of the optimized structures of $\mathbf{4}^{+}$and $\mathbf{4}^{\cdot \pm}$

20. References 


\section{Experimental Section}

General: Chemicals were sourced either from Sigma-Aldrich, Spectrochem India, Loba-chemie, or Thomas-Baker-India and were used as received. Thin layer chromatography (TLC) was carried out on aluminium plates coated with silica gel mixed with fluorescent indicator and was sourced from Merck, Germany. NMR $\left({ }^{1} \mathrm{H},{ }^{13} \mathrm{C}\right.$, DEPT 135 and APT) spectra were recorded on a Bruker $500 \mathrm{MHz}$ spectrometer in $\mathrm{CDCl}_{3}$ with TMS as a standard. Spin multiplicities are reported as a singlet (s), doublet (d), and triplet $(\mathrm{t})$ with coupling constants $(J$ ) given in Hz, or multiplet $(\mathrm{m})$. MALDI-TOF mass spectral data were obtained using a Bruker made Auto flex TOF/TOF instrument with laser repetition rate of 50 psec. $\alpha$-Cyano-4-hydroxycinnamic acid and 1,8,9-Anthracenetriol were used as the matrix for MALDI-TOF mass spectrometry. The compound NDI-(CN) ${ }_{2}{ }^{1}$ and the starting material 2,3-dibromonaphthalene-1,4,5,8-tetracarboxylic acid bisimide (NDI-Br2) ${ }^{2}$ were synthesized by following the earlier reported procedures.

UV-vis-NIR and IR Spectroscopy: UV-vis-NIR spectra were recorded on a JASCO V-670UV-visNIR Spectrophotometer. All the spectroscopic experiments were carried out in UV Grade $\mathrm{CHCl}_{3}$ and $\mathrm{MeCN}$ which was sourced from Spectrochem, India. Infrared spectra were recorded in $\mathrm{KBr}$ pellet using a Varian 3100 FT-IR instrument.

Cyclic and Differential Pulse Voltammetry (CV/DPV): CV and DPV were carried out using a computer controlled potentiostat (CHI 650C) and a standard three electrode arrangement that consisted of both platinum working and auxiliary electrodes and saturated calomel (SCE) as reference electrode. All electrochemical measurements were carried out in argon-purged MeCN with n$\mathrm{Bu}_{4} \mathrm{NPF}_{6}$ as the supporting electrolyte. $\mathrm{CV}$ studies of the all molecules $(0.5 \mathrm{mM})$ were performed in degassed $\mathrm{MeCN}$ under argon atmosphere and the scan rate for the measurements was typically 300 $\mathrm{mV} / \mathrm{s}$.

Theoretical calculations: The ground-state geometry optimization was carried out applying the density functional theory (DFT) with the Becke three-parameter ${ }^{3}$ hybrid exchange functional in concurrence with the Lee-Yang-Parr gradient-corrected correlation function (B3LYP and UB3LYP functional $)^{4}$ with the $6-311 \mathrm{G}^{+}(\mathrm{d}, \mathrm{p})$ basis set as implemented in Gaussian 09W. ${ }^{5}$ All the geometries were optimized without any constrain.

X-ray Crystallography: X-ray suitable good quality single crystals of $\mathbf{1}^{+} \mathbf{B r}{ }^{-}$were grown in a solvent mixture of DCM and toluene by slow evaporation at RT, while single crystals of zwitterionic radical 
$\mathbf{1}^{{ }^{ \pm}}$were grown by diffusion of n-hexane in DCM at room temperature. The X-ray data of $\mathbf{1}^{+} \mathbf{B r}^{-}$and $\mathbf{1}^{\cdot \pm}$ were collected by mounting the crystal with paratone oil in a loop. X-ray reflections were collected on Bruker D8 Quest diffractometer with CMOS detector using Mo-Ka radiation, generated from the micro-focus sealed tube. Data collection was performed using $\varphi$ and $\omega$-scans of $0.5^{\circ}$ steps at $100 \mathrm{~K}$. Cell determination, data collection and data reduction were performed with the help of Bruker APEX2 (version: 2014.3-0) software. The structures were solved by intrinsic phasing method (SHELXS-97) and refined by full-matrix least squares refinement method based on $\mathrm{F}^{2}$, using, SHELXL-2014. All non-hydrogen atoms were refined anisotropically. All hydrogen atoms were fixed geometrically with their $\mathrm{U}_{\text {iso }}$ values 1.2 times of the phenylene and methylene carbons and 1.5 times of the methyl carbon using a riding model. The crystal structure data are deposited to Cambridge Structural Database with CCDC number 1952950, 1952961.

\section{Precursor molecules:}

Monoamino-monobromo compounds

\section{Mono phosphonium} NDI molecules:
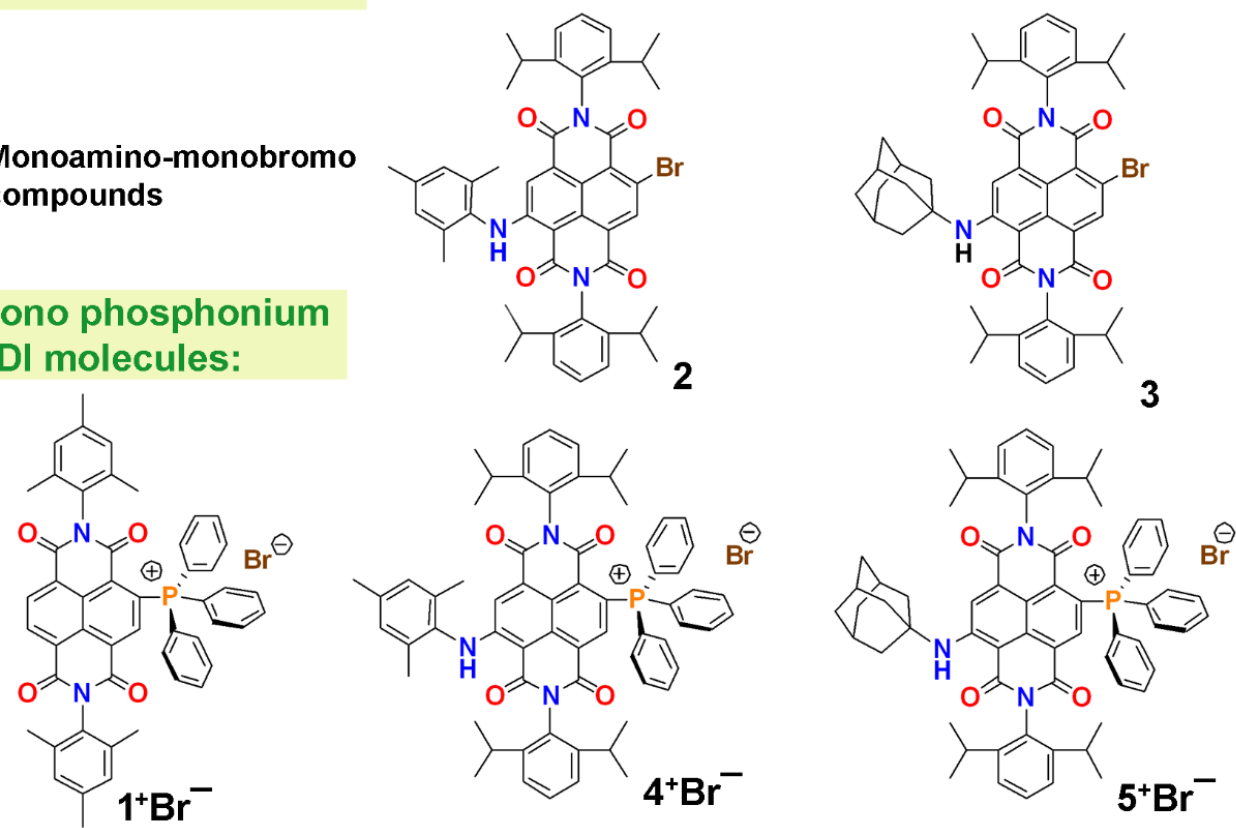

NDI-centred

zwitterionic radicals:
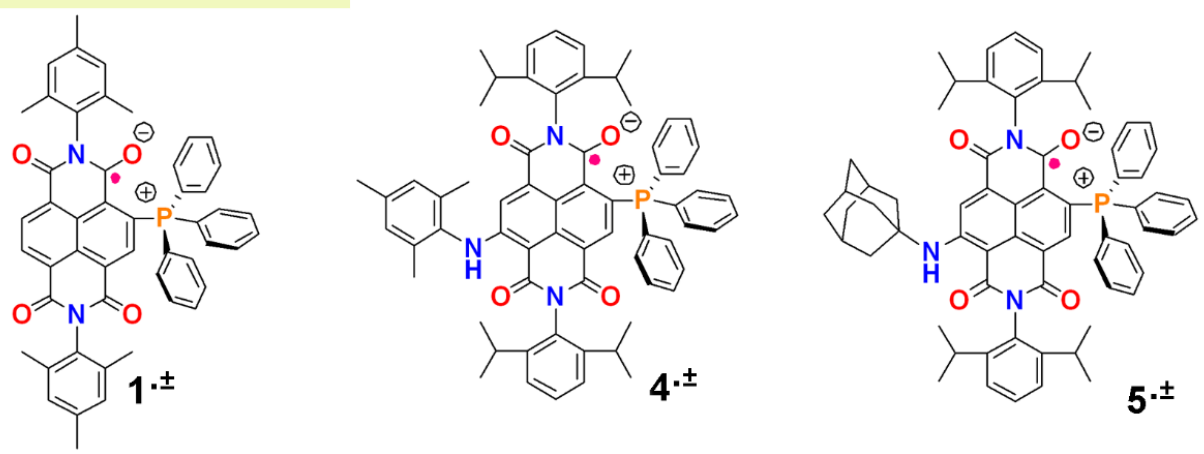

Chart S1: Molecular structures of precursor, cationic, and zwitterionic radical molecules. 


\section{Synthesis and Characterization}

Synthesis of $\mathbf{1}^{+} \mathbf{B r}^{-}$: In a pressure tube containing $2 \mathrm{~mL}$ dry bezonitrile, N,N'-2,4,6-trimethylaniline2-bromonaphthalene-1,4,5,8-tetracarboxylic acid bisimide (200 mg, $0.34 \mathrm{mmol}$ ), triphenylphosphine (270 mg, $1.03 \mathrm{mmol}$ ) was added and the resulting mixture was heated at $130{ }^{\circ} \mathrm{C}$ using oil bath for 24 h. The reaction mixture was gradually brought to room temperature and precipitated using excess of hexane. The obtained solid was purified by column chromatography using $\mathrm{CHCl}_{3}: \mathrm{MeOH}(9.5: 0.5)$ as eluent yield: $204 \mathrm{mg}, 70 \%$, yellow colour compound. ${ }^{1} \mathrm{H}$ NMR $\left(500 \mathrm{MHz}, \mathrm{CDCl}_{3}, \mathrm{TMS}\right): \delta(\mathrm{ppm})=$ $9.02(\mathrm{~s}, 2 \mathrm{H}), 8.42(\mathrm{~d}, 1 \mathrm{H}), 7.88-7.63(\mathrm{~m}, 15 \mathrm{H}), 7.00(\mathrm{~s}, 2 \mathrm{H}), 6.85(\mathrm{~s}, 2 \mathrm{H}), 2.32(\mathrm{~s}, 3 \mathrm{H}), 2.25(\mathrm{~s}, 3 \mathrm{H})$, 2.09 (s, 6H), 1.79 (s, 6H). ${ }^{13} \mathrm{C} \mathrm{NMR}\left(125 \mathrm{MHz}, \mathrm{CDCl}_{3}, \mathrm{TMS}\right): \delta(\mathrm{ppm})=161.4,161.3,161.0,139.2$, 139.1, 136.2, 136.1, 135.2, 135.1, 134.5, 133.9, 132.3, 132.3, 130.8, 130.8, 130.4, 130.4, 130.3, 130.2, $129.9,129.4,129.3,129.3,127.8,127.7,127.7,127.2,122.8,122.1,21.1,21.1,17.9,17.7 .{ }^{31} \mathrm{P}(202$ $\left.\mathrm{MHz}, \mathrm{CDCl}_{3}, 298 \mathrm{~K}, \mathrm{H}_{3} \mathrm{PO}_{4}\right): \delta=30.93$; Melting Point $=280-286^{\circ} \mathrm{C}$, HRMS (ESI-TOF) m/z: [M $\mathrm{Br}]^{+}$Calcd for $\mathrm{C}_{50} \mathrm{H}_{40} \mathrm{~N}_{2} \mathrm{O}_{4} \mathrm{P}$ 763.2720; found 763.2738. FTIR $\left(\mathrm{KBr}, \mathrm{cm}^{-1}\right)$ : 2957, 2925, 2857, 1705 , 1655, 1571, 1460, 1437, 1257, 1105.

\section{General procedure for synthesis of 2-3:}

In a $50 \mathrm{~mL}$ round bottomed (RB) flask containing $10 \mathrm{~mL}$ dry $p$-dioxane, N,N'-2,6-diisopropylaniline2,3-dibromonaphthalene-1,4,5,8-tetracarboxylic acid bisimide (500 $\mathrm{mg}, 0.67 \mathrm{mmol})$ and the primary amine $(3.37 \mathrm{mmol})$ were added. The mixture was refluxed on oil bath and the progress of the reaction was monitored by TLC. The reaction mixture was gradually brought to room temperature and dried under reduced pressure. The obtained solid was purified by column chromatography using $\mathrm{CHCl}_{3}$ :Hexane (8:2) as eluent.

Synthesis of 2: The product was isolated as reddish-pink colour solid; $387 \mathrm{mg}$, 72\%. Melting point: $>350{ }^{\circ} \mathrm{C} .{ }^{1} \mathrm{H} \mathrm{NMR}\left(500 \mathrm{MHz}, \mathrm{CDCl}_{3}, \mathrm{TMS}\right): \delta(\mathrm{ppm})=11.17(\mathrm{~s}, 1 \mathrm{H}), 8.96(\mathrm{~s}, 1 \mathrm{H}), 7.79(\mathrm{~s}, 1 \mathrm{H})$, 7.47-7.40 (m, 1H), $7.38(\mathrm{t}, 1 \mathrm{H}, J=8 \mathrm{~Hz}), 7.32(\mathrm{~s}, 1 \mathrm{H}), 7.30(\mathrm{~s}, 1 \mathrm{H}), 7.23(\mathrm{~d}, 2 \mathrm{H}, J=8 \mathrm{~Hz}), 6.91(\mathrm{~s}$, 2H), 2.68-2.62 (m, 2H), 2.59-2.53 (m, 2H), $2.23(\mathrm{~s}, 3 \mathrm{H}), 2.08(\mathrm{~s}, 6 \mathrm{H}), 1.14-1.09(\mathrm{~m}, 24 \mathrm{H}) .{ }^{13} \mathrm{C} \mathrm{NMR}$ $\left(125 \mathrm{MHz}, \mathrm{CDCl}_{3}, \mathrm{TMS}\right): \delta(\mathrm{ppm})=161.8,161.5,160.9,160.9,151.9,145.5,145.3,139.6,138.9$, 138.0, 135.1, 131.7, 130.2, 130.2, 130.2, 129.9, 129.9, 129.8, 129.1, 128.6, 128.0, 125.6, 124.6, 124.4, 124.3, 124.1, 124.0, 123.1, 122.4, 121.4, 100.3, 29.7, 29.4, 29.3, 29.2, 23.9, 23.9, 23.9, 23.9, 21.0, and 18.9. HRMS (ESI-TOF) m/z: $[\mathrm{M}+\mathrm{H}]^{+}$Calcd for $\mathrm{C}_{47} \mathrm{H}_{49} \mathrm{~N}_{3} \mathrm{O}_{4} \mathrm{Br}$ 798.2906; found 798.2931. FTIR (KBr, cm $\left.{ }^{-1}\right):$ 2963, 2928, 2867, 1720, 1685, 1646, 1579, 1482, 1230. 
Synthesis of 3: The product was isolated as reddish-pink colour solid; $410 \mathrm{mg}, 75 \%$. Melting point: 334-337 ${ }^{\circ} \mathrm{C} .{ }^{1} \mathrm{H}$ NMR $\left(500 \mathrm{MHz}, \mathrm{CDCl}_{3}, \mathrm{TMS}\right): \delta(\mathrm{ppm})=10.41(\mathrm{~s}, 1 \mathrm{H}), 8.97(\mathrm{~s}, 1 \mathrm{H}), 8.75(\mathrm{~s}, 1 \mathrm{H})$, 7.53-7.47 (m, 2H), 7.37-7.33 (m, 4H), 2.72-2.63 (m, 4H), $2.20(\mathrm{~s}, 9 \mathrm{H}), 1.76(\mathrm{~s}, 6 \mathrm{H}), 1.20-1.16(\mathrm{~m}$, 24H). ${ }^{13} \mathrm{C} \mathrm{NMR}\left(125 \mathrm{MHz}, \mathrm{CDCl}_{3}\right.$, TMS): $\delta(\mathrm{ppm})=166.3,161.9,161.6,151.9,145.5,145.4,138.6$, 130.3, 129.9, 129.8, 126.7, 124.3, 124.2, 123,9, 123.7, 122.1, 120.4, 100.3, 54.2, 42.7, 36.0, 29.7, 29.5, 29.3, 29.2, 24.1, 24.0, 23.9, 1.0. HRMS (ESI-TOF) m/z: $[\mathrm{M}+\mathrm{K}]^{+}$Calcd for $\mathrm{C}_{48} \mathrm{H}_{52} \mathrm{~N}_{3} \mathrm{O}_{4} \mathrm{BrK}$ 852.2778; found 852.2788. FTIR $\left(\mathrm{cm}^{-1}\right)$ : 2960, 2920, 2852, 1719, 1682, 1640, 1586, 1438, 1262 , 1226.

\section{General procedure for synthesis of $4^{+} \mathrm{Br}^{-}-5^{+} \mathrm{Br}^{-}$:}

In a pressure tube containing $2 \mathrm{~mL}$ dry benzonitrile, $2 / 3(0.25 \mathrm{mmol})$ and the triphenylphosphine $(2.50 \mathrm{mmol})$ were added. The reaction mixture was allowed to heat at $130{ }^{\circ} \mathrm{C}$ using oil bath. The colour of the solution became dark purple with the progress of the reaction. After $24 \mathrm{~h}$, the reaction mixture was gradually brought to room temperature and precipitates by the addition of excess of hexane, and washed thoroughly with the excess of diethylether to obtain the analytically pure compound.

Synthesis of $\mathbf{4}^{+} \mathbf{B r}^{-}$: The product was isolated as a brown colour solid; $212 \mathrm{mg}, 80 \% .{ }^{1} \mathrm{H}$ NMR (500 MHz, $\mathrm{CDCl}_{3}$, TMS): $\delta(\mathrm{ppm})=11.69(\mathrm{~s}, 1 \mathrm{H}), 8.37(\mathrm{~d}, 1 \mathrm{H}, J=15 \mathrm{~Hz}), 7.93(\mathrm{~s}, 1 \mathrm{H}), 7.65-7.58(\mathrm{~m}$, 15H), $7.40(\mathrm{t}, 1 \mathrm{H}, J=7.5 \mathrm{~Hz}), 7.37-7.25(\mathrm{~m}, 3 \mathrm{H}), 7.04(\mathrm{~d}, 2 \mathrm{H}, J=7.5 \mathrm{~Hz}), 6.94(\mathrm{~s}, 2 \mathrm{H}),, 2.65(\mathrm{~m}$, 2H), $2.29(\mathrm{~m}, 2 \mathrm{H}), 2.24(\mathrm{~s}, 3 \mathrm{H}), 2.12(\mathrm{~s}, 6 \mathrm{H}), 1.09$ (d, 12H, J = 6.5 Hz), $0.92(\mathrm{~d}, 6 \mathrm{H}, J=6.5 \mathrm{~Hz}), 0.56$ $(\mathrm{d}, 6 \mathrm{H}, J=6.5 \mathrm{~Hz}) .{ }^{13} \mathrm{C} \mathrm{NMR}\left(125 \mathrm{MHz}, \mathrm{CDCl}_{3}, \mathrm{TMS}\right): \delta(\mathrm{ppm})=166.4,162.7,161.6,161.4,154.1$, 145.5, 145.3, 138.7, 138.6, 134.9, 134.6, 130.9, 130.4, 130.3, 130.1, 130.0, 129.9, 129.6, 128.7, 128.5, 125.8, 124.4, 124.2, 124.1, 124.0, 113.8, 113.1, 99.7, 29.2, 29.1, 24.2, 24.0, 24.0, 23.8, 21.0, 18.4. ${ }^{31} \mathrm{P}\left(202 \mathrm{MHz}, \mathrm{CDCl}_{3}, 298 \mathrm{~K}, \mathrm{H}_{3} \mathrm{PO}_{4}\right): \delta=30.09$; Melting Point $=210-212{ }^{\circ} \mathrm{C}$. HRMS (ESI-TOF) m/z: $[\mathrm{M}-\mathrm{Br}]^{+}$Calcd for $\mathrm{C}_{65} \mathrm{H}_{63} \mathrm{~N}_{3} \mathrm{O}_{4} \mathrm{P}$ 980.4551; found 980.4570. FTIR (KBr, $\left.\mathrm{cm}^{-1}\right)$ : 2964, 2927, 2870, 1720, 1703, 1667, 1644, 1620, 1587, 1483, 1440, 1366, 1230.

Synthesis of $\mathbf{5}^{+} \mathbf{B r}^{-}$: The product was isolated as dark red colour solid; $230 \mathrm{mg}, 85 \%$. ${ }^{1} \mathrm{H}$ NMR $(500$ $\mathrm{MHz}, \mathrm{CDCl}_{3}$, TMS): $\delta(\mathrm{ppm})=10.94(\mathrm{~s}, 1 \mathrm{H}), 8.81(\mathrm{~s}, 1 \mathrm{H}), 8.27(\mathrm{~d}, 1 \mathrm{H}), 7.65-7.57(\mathrm{~m}, 15 \mathrm{H}), 7.38(\mathrm{t}$, $1 \mathrm{H}, J=7.5 \mathrm{~Hz}), 7.29$ (t, 1H, J=7.5 Hz), $7.24(\mathrm{~d}, 2 \mathrm{H}, \mathrm{J}=8 \mathrm{~Hz}), 7.08(\mathrm{~d}, 2 \mathrm{H}, J=8 \mathrm{~Hz}), 2.55$ (m, 2H), $2.37(\mathrm{~m}, 2 \mathrm{H}), 2.15(\mathrm{~s}, 9 \mathrm{H}), 1.77(\mathrm{~s}, 6 \mathrm{H}), 1.08-0.99(\mathrm{~m}, 12 \mathrm{H}), 0.59(\mathrm{~d}, 6 \mathrm{H}, J=6.5 \mathrm{~Hz}) .{ }^{13} \mathrm{C} \mathrm{NMR}(125$ $\mathrm{MHz}, \mathrm{CDCl}_{3}$, TMS): $\delta(\mathrm{ppm})=166.1,162.8,161.7,161.6,154.1,145.4,145.4,138.4,130.4,130.3$, 130.1, 130.0, 129.9, 129.9, 129.8, 128.7, 127.2 , 126.8, 124.4, 124.1, 123.3, 99.6, 55.57, 42.9, 35.8, 
29.7, 29.4, 29.4, 29.1, 24.2, 24.1, 24.1, 23.9. ${ }^{31} \mathrm{P}$ (202 MHz, CDCl3, $\left.298 \mathrm{~K}, \mathrm{H}_{3} \mathrm{PO}_{4}\right): \delta=29.90$; Melting Point $=285-288{ }^{\circ} \mathrm{C}$. HRMS (ESI-TOF) $\mathrm{m} / \mathrm{z}:[\mathrm{M}-\mathrm{Br}]^{+}$Calcd for $\mathrm{C}_{66} \mathrm{H}_{67} \mathrm{~N}_{3} \mathrm{O}_{4} \mathrm{P} 996.4869$; found 996.4882. FTIR (KBr, $\left.\mathrm{cm}^{-1}\right)$ : 2964, 2909, 2868, 1722, 1692, 1664, 1641, 1617, 1595, 1535 , $1440,1102$.

\section{General procedure for synthesis of $1^{\cdot \pm}, 4^{\cdot \pm}$ and $5^{\cdot \pm}$ :}

The monophosphonium monocationic compound $\left(\mathbf{1}^{+} \mathbf{B r}^{-}, \mathbf{4}^{+} \mathbf{B r}^{-}\right.$and $\left.\mathbf{5}^{+} \mathbf{B r}^{-}\right)(100 \mathrm{mg})$ was transferred to a $50 \mathrm{~mL} \mathrm{RB}$ containing $5 \mathrm{~mL} \mathrm{MeCN}$ and $\mathrm{Na}_{2} \mathrm{~S}$ solution (dissolved in $\mathrm{MeOH}$ ) was added to it. The reaction mixture was allowed to stir at room temperature. The reaction progress was monitored by UV-vis-NIR spectroscopy. The reaction mixture was dried under vacuum and washed with an excess of hexane. The obtained solid was dissolved in DCM and filtered, the resulting DCM solution was dried under vacuum to get analytically pure zwitterionic radical in good yield.

Synthesis of 1.*. The product was isolated as blackish green colour solid; $72 \mathrm{mg}, 80 \%$. Melting Point $=290-294{ }^{\circ} \mathrm{C}$. HRMS (ESI-TOF) m/z: Calcd for $\mathrm{C}_{50} \mathrm{H}_{40} \mathrm{~N}_{2} \mathrm{O}_{4} \mathrm{P}$ 763.2720; found 763.2740. FTIR $\left(\mathrm{KBr}, \mathrm{cm}^{-1}\right): 2916,2855,1676,1651,1602,1552,1492,1441,1114,1002$.

Synthesis of $4^{\cdot \pm}$ : The product was isolated as dark purple colour solid; $74 \mathrm{mg}, 80 \%$. Melting Point $=224-227{ }^{\circ} \mathrm{C}$, HRMS (ESI-TOF) m/z: Calcd for $\mathrm{C}_{65} \mathrm{H}_{63} \mathrm{~N}_{3} \mathrm{O}_{4} \mathrm{P}$ 980.4551; found 980.4501. FTIR $\left(\mathrm{KBr}, \mathrm{cm}^{-1}\right)$ : 2961, 2927, 2867, 1664, 1656, 1649, 1642, 1619, 1586, 1466, 1439.

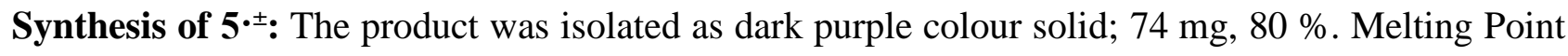
$=297-301{ }^{\circ} \mathrm{C}$, HRMS (ESI-TOF) m/z: Calcd for $\mathrm{C}_{66} \mathrm{H}_{67} \mathrm{~N}_{3} \mathrm{O}_{4} \mathrm{P}, 996.4869$, found 996.4911. FTIR $\left(\mathrm{KBr}, \mathrm{cm}^{-1}\right):$ 2961, 2927, 2867, 1664, 1656, 1649, 1642, 1619, 1586, 1466, 1439. 


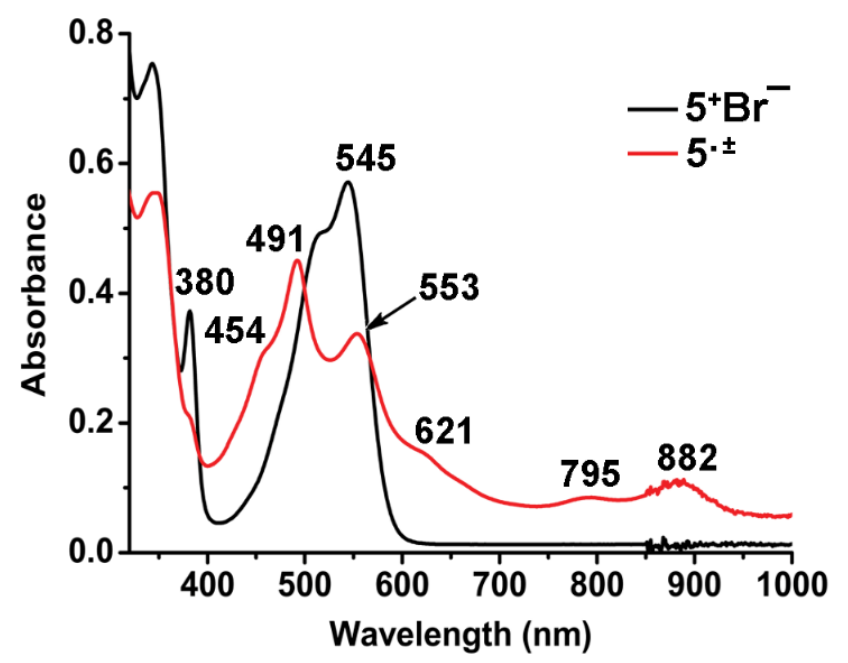

Figure S1. UV-vis-NIR spectra of compound $\mathbf{5}^{+} \mathbf{B r}^{-}$and its corresponding zwitterionic radical $\mathbf{5}^{\cdot \pm}$ in $0.05 \mathrm{mM}$ MeCN solution.

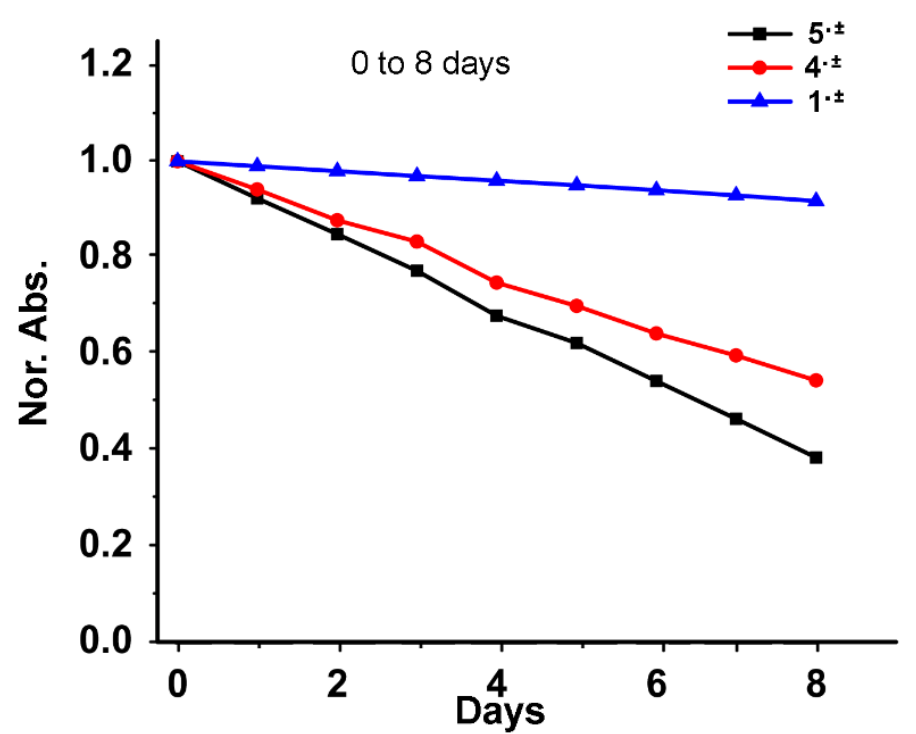

Figure S2. Plot of time-dependent absorbance of $\mathbf{1}^{\cdot \pm}$ (at $461 \mathrm{~nm}$ ), $\mathbf{4}^{\cdot \pm}$ (at $862 \mathrm{~nm}$ ) and $\mathbf{5}^{\cdot \pm}$ (at $882 \mathrm{~nm}$ ) in the solution state (in $0.25 \mathrm{mM} \mathrm{MeCN}$ solution, under ambient condition). The half-life of $\mathbf{1}^{\cdot \pm}, \mathbf{4}^{\cdot \pm}$ and $\mathbf{5}^{\star \pm}$ was found to be $\sim 65,9$ and 6 days, respectively.

a)

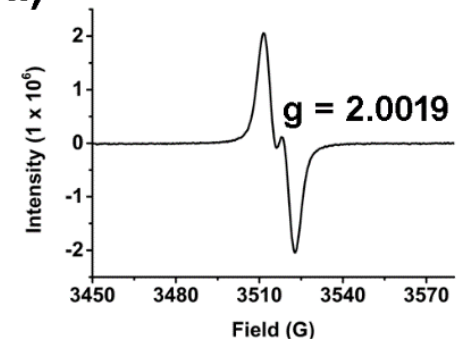

b)

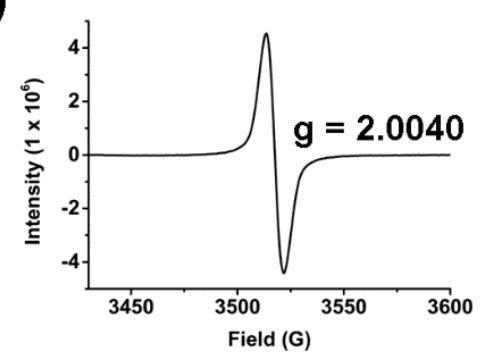

c)

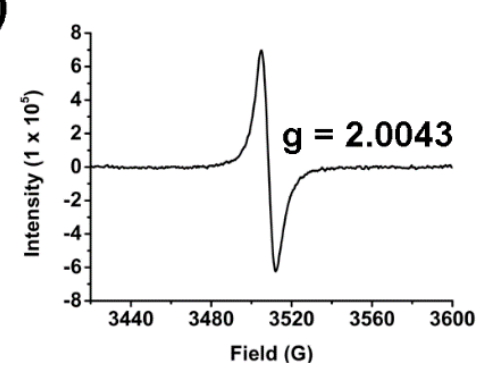

Figure S3: EPR spectra of all the zwitterionic radical compounds $\mathbf{1}^{\cdot \pm}(\mathrm{a}), \mathbf{4}^{\cdot \pm}(\mathrm{b})$ and $\mathbf{5}^{ \pm}(\mathrm{c})$ in $1 \mathrm{mM}$ $\mathrm{MeCN}$ solution with their corresponding g value. 

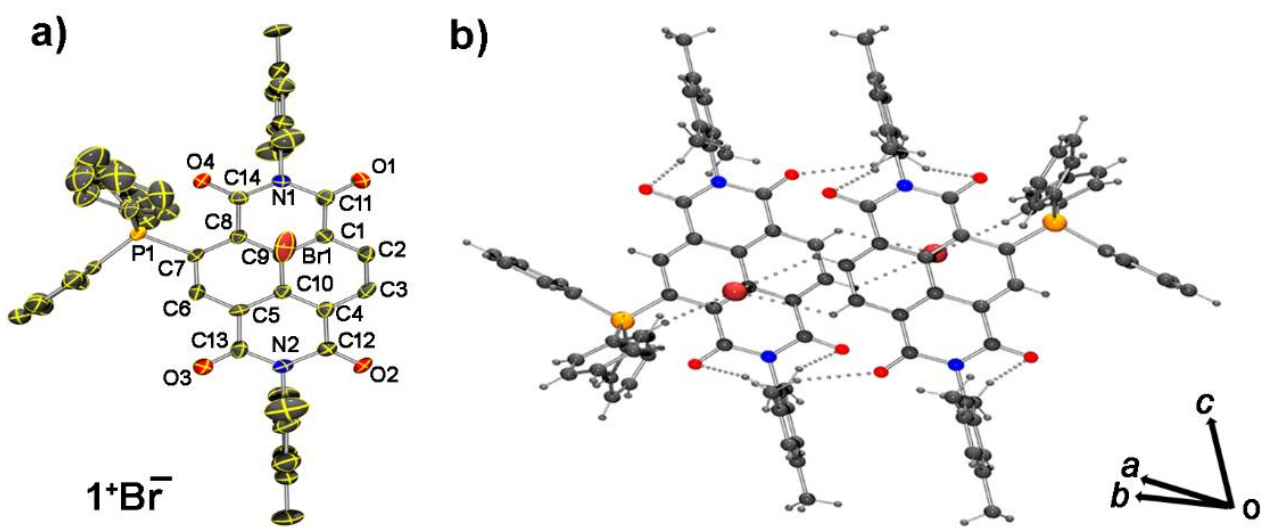

Figure S4: ORTEP representation of $\mathbf{1}^{+} \mathbf{B r}^{-}$(with $50 \%$ probability) with the numbering scheme (a) Anion- $\pi$ and $\mathrm{H}$-bonding induced dimeric structure of compound $\mathbf{1}^{+} \mathbf{B r}^{-}(\mathrm{b})$.

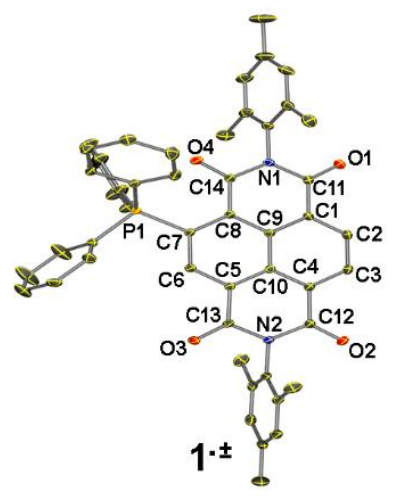

Figure S5: Ortep representation of $\mathbf{1}^{. \pm}$with the numbering scheme (with $50 \%$ probability).

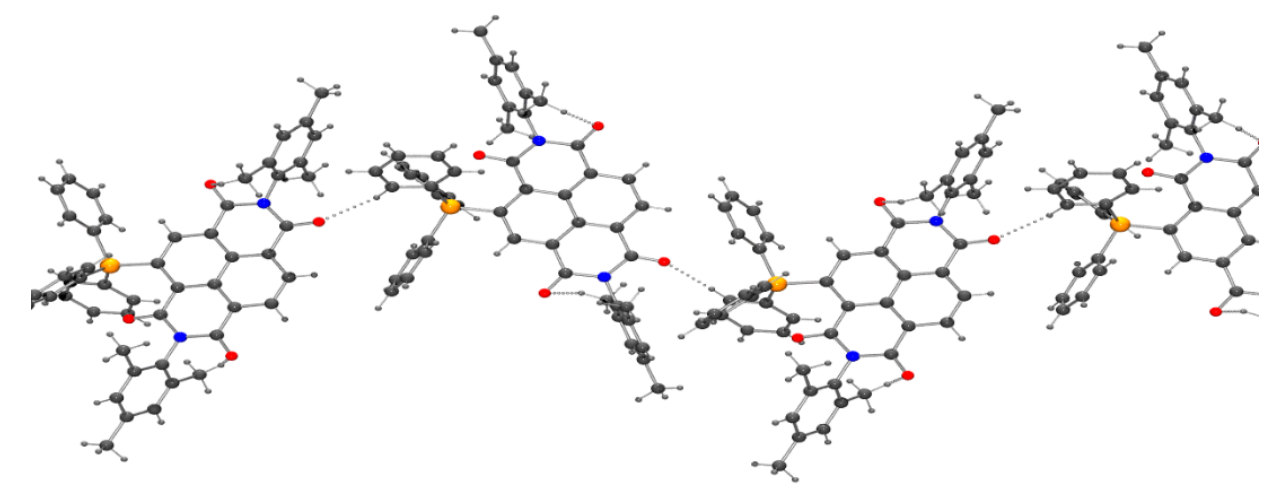

Figure S6: H-bonding induced supramolecular array along the $b$ axis in the crystal structure of $\mathbf{1}^{\bullet \pm}$. 
Table S1: Selected bond lengths ( $(\AA)$ of X-ray crystal structures of $\mathbf{1}^{+} \mathbf{B r}^{-}$and $\mathbf{1}^{\cdot \pm}$.

\begin{tabular}{|c|c|c|}
\hline Bond & $\mathrm{1}^{+} \mathrm{Br}^{-}$ & $1 \cdot \pm$ \\
\hline $\mathrm{C} 1-\mathrm{C} 2$ & 1.365 & 1.406 \\
\hline $\mathrm{C} 2-\mathrm{C} 3$ & 1.383 & 1.380 \\
\hline $\mathrm{C} 3-\mathrm{C} 4$ & 1.383 & 1.404 \\
\hline $\mathrm{C} 4-\mathrm{C} 10$ & 1.394 & 1.403 \\
\hline $\mathrm{C} 10-\mathrm{C} 5$ & 1.413 & 1.418 \\
\hline $\mathrm{C} 5-\mathrm{C} 6$ & 1.374 & 1.396 \\
\hline $\mathrm{C} 6-\mathrm{C} 7$ & 1.402 & 1.392 \\
\hline $\mathrm{C} 7-\mathrm{C} 8$ & 1.405 & 1.430 \\
\hline $\mathrm{C} 8-\mathrm{C} 9$ & 1.403 & 1.416 \\
\hline $\mathrm{C} 9-\mathrm{C} 1$ & 1.421 & 1.412 \\
\hline $\mathrm{C} 9-\mathrm{C} 10$ & 1.410 & 1.422 \\
\hline $\mathrm{C} 1-\mathrm{C} 11$ & 1.470 & 1.463 \\
\hline $\mathrm{C} 4-\mathrm{C} 12$ & 1.483 & 1.462 \\
\hline $\mathrm{C} 5-\mathrm{C} 13$ & 1.487 & 1.459 \\
\hline $\mathrm{C} 8-\mathrm{C} 14$ & 1.479 & 1.436 \\
\hline $\mathrm{C} 11-\mathrm{O} 1$ & 1.209 & 1.222 \\
\hline $\mathrm{C} 12-\mathrm{O} 2$ & 1.194 & 1.219 \\
\hline $\mathrm{C} 13-\mathrm{O} 3$ & 1.218 & 1.223 \\
\hline $\mathrm{C} 14-\mathrm{O} 4$ & 1.226 & 1.237 \\
\hline $\mathrm{C} 11-\mathrm{N} 1$ & 1.411 & 1.404 \\
\hline $\mathrm{C} 14-\mathrm{N} 1$ & 1.381 & 1.397 \\
\hline $\mathrm{C} 12-\mathrm{N} 2$ & 1.414 & 1.402 \\
\hline $\mathrm{C} 13-\mathrm{N} 2$ & 1.389 & 1.402 \\
\hline $\mathrm{C} 7-\mathrm{P} 1$ & 1.827 & 1.794 \\
\hline
\end{tabular}



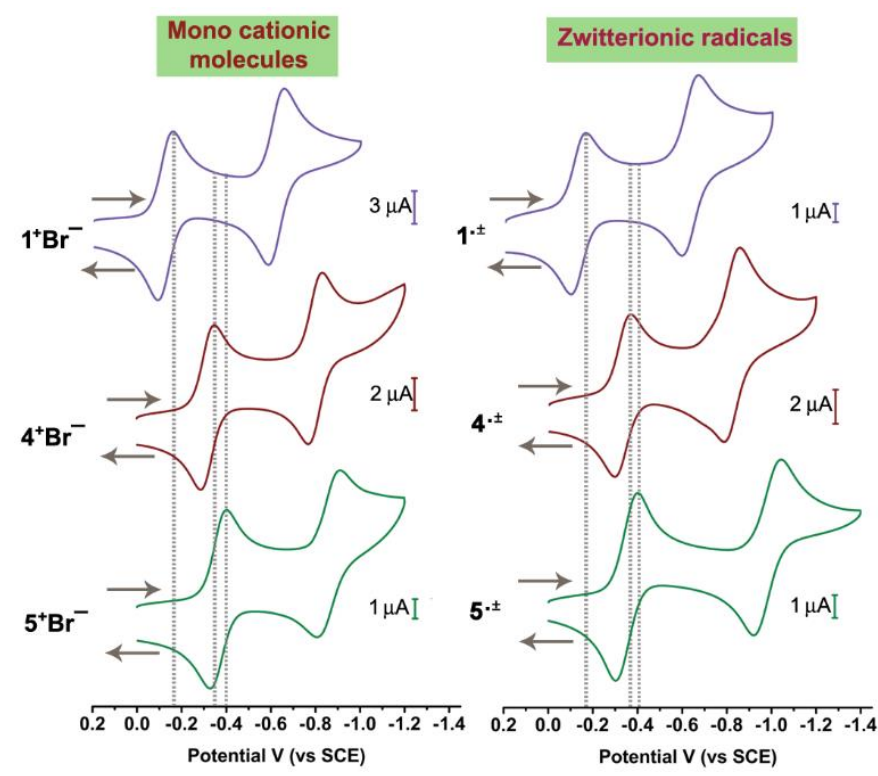

Figure S7a: CV studies of $\mathbf{1}^{+} \mathbf{B r}^{-}, \mathbf{4}^{+} \mathbf{B r}^{-}, \mathbf{5}^{+} \mathbf{B r}^{-},($left $)$, and $\mathbf{1}^{\bullet \pm}, \mathbf{4}^{\cdot \pm}, \mathbf{5}^{\cdot \pm}$ (right) in $\mathrm{MeCN}(0.5 \mathrm{mM})$ with $0.1 \mathrm{M} \mathrm{TBAPF}_{6}$ as electrolyte, using saturated calomel as reference and platinum wire as working and auxiliary electrodes.

Table S2: Reduction potentials and LUMO levels of $\mathbf{1}^{+} \mathbf{B r}^{-}, 4^{+} \mathbf{B r}^{-}$and $\mathbf{5}^{+} \mathbf{B r}^{-}$in $\mathrm{MeCN}$.

\begin{tabular}{cccc}
\hline Entry & $\mathbf{E}_{\mathbf{1}}{ }^{\text {red }}(\mathbf{V})$ & $\mathbf{E}_{2}^{\text {red }}(\mathbf{V})$ & LUMO $(\mathbf{e V})$ \\
\hline $\mathbf{1}^{+} \mathbf{B r}^{-}$ & -0.119 & -0.615 & -4.281 \\
$\mathbf{4}^{+} \mathbf{B r}^{-}$ & -0.316 & -0.798 & -4.083 \\
$\mathbf{5}^{+} \mathbf{B r}^{-}$ & -0.364 & -0.859 & -4.036 \\
\hline
\end{tabular}

All potentials reported as $\mathrm{E}_{1 / 2}=\left(\left(\mathrm{E}_{\mathrm{ap}}+\mathrm{E}_{\mathrm{cp}}\right) / 2\right)$ in $\mathrm{V}$ where $\mathrm{E}_{\mathrm{ap}}$ and $\mathrm{E}_{\mathrm{cp}}$ are the anodic and cathodic peak potentials, respectively. $\mathrm{LUMO}=-\left(4.4+\mathrm{E}^{1}\right.$ red $) \mathrm{eV}$. 


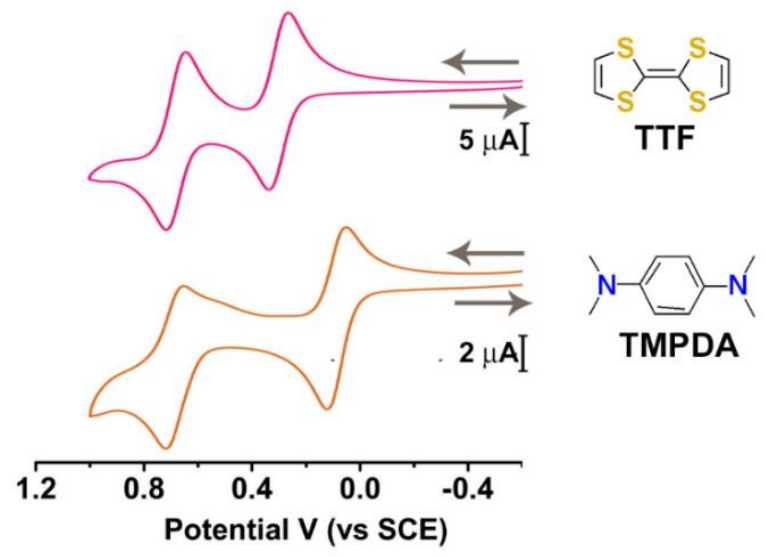

Figure S7b: Cyclic Voltammogram results of compound TTF and TMPDA $(0.5 \mathrm{mM})$ in degassed $\mathrm{MeCN}$ with $0.1 \mathrm{M} \mathrm{TBAPF}_{6}$ at room temperature, using saturated calomel as reference electrode, and platinum wire as working, and auxiliary electrode.

Table S3. Redox potentials of $\mathbf{1}^{\cdot \pm}, \mathbf{4}^{\cdot \pm}, \mathbf{5}^{\cdot \pm}$, TMPDA and TTF in MeCN.

\begin{tabular}{|c|c|c|c|c|}
\hline Entry & $\mathbf{E}_{\text {ox }}^{\mathbf{1}}(\mathbf{V})$ & $\begin{array}{c}\mathbf{E}^{\mathbf{1}} \mathbf{r e d} \\
(\mathbf{V})\end{array}$ & $\mathbf{E}_{\text {ox }}^{\mathbf{2}}(\mathbf{V})$ & $\begin{array}{c}\mathbf{S O M O}^{\mathrm{a}} / \\
\mathbf{H O M O}^{\mathbf{b}}(\mathbf{e V})\end{array}$ \\
\hline $\mathbf{1}^{\bullet \pm}$ & -0.128 & -0.629 & - & $-4.272^{\mathrm{a}}$ \\
\hline $\mathbf{4}^{\cdot \pm}$ & -0.317 & -0.810 & - & $-4.083^{\mathrm{a}}$ \\
\hline $\mathbf{5}^{\bullet \pm}$ & -0.364 & -0.981 & - & $-4.036^{\mathrm{a}}$ \\
\hline TMPDA & +0.086 & - & +0.685 & $-4.486^{\mathrm{b}}$ \\
\hline TTF & +0.295 & - & +0.675 & $-4.695^{\mathrm{b}}$ \\
\hline
\end{tabular}

All potentials reported as $\mathrm{E}_{1 / 2}=\left[\left(\mathrm{E}_{\mathrm{ap}}+\mathrm{E}_{\mathrm{cp}}\right) / 2\right]$ in $\mathrm{V}$ where $\mathrm{E}_{\mathrm{ap}}$ and $\mathrm{E}_{\mathrm{cp}}$ are the anodic and cathodic peak potentials, respectively. SUMO, HOMO $=-\left(4.4+\mathrm{E}_{\text {ox }}^{1}\right) \mathrm{eV}$. 


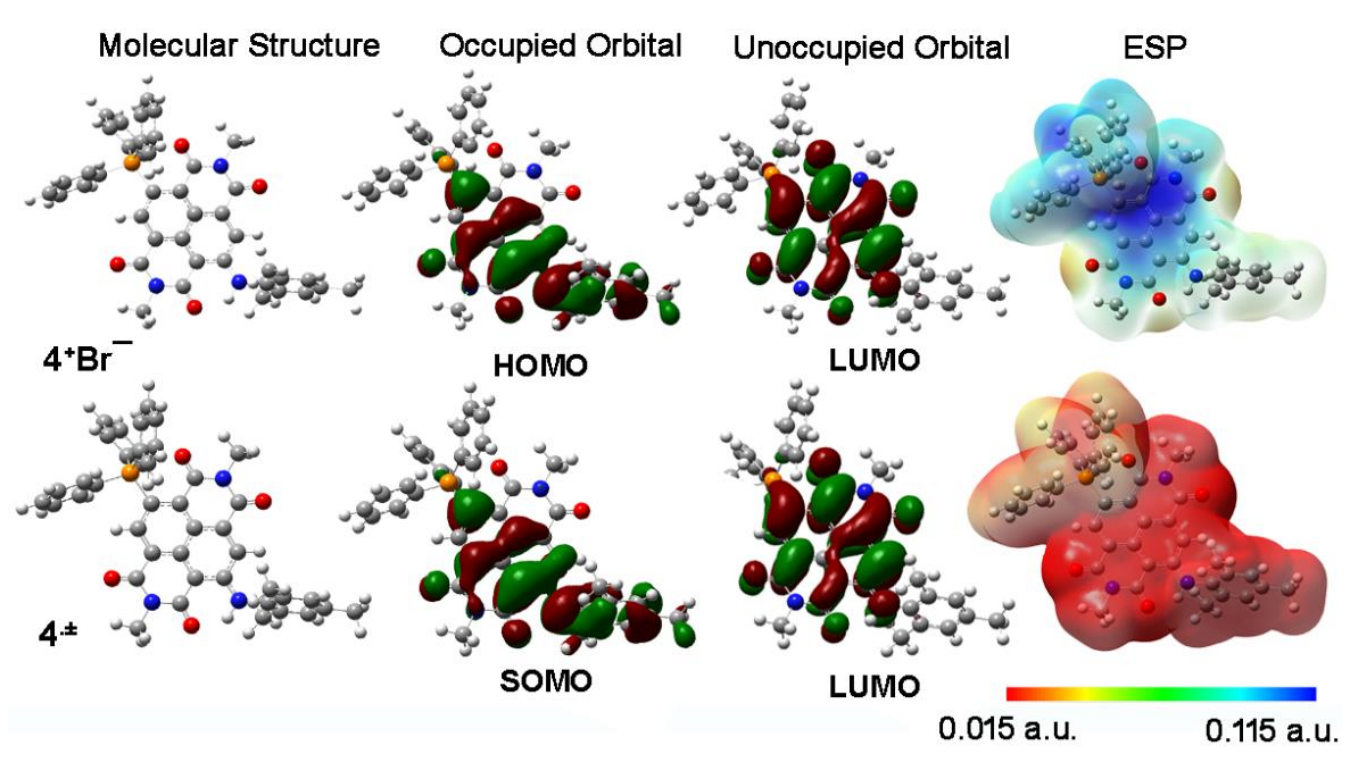

Figure S8a: Optimized molecular structures of $\mathbf{4}^{+} \mathbf{B r}^{-}$and $\mathbf{4}^{\cdot \pm}$ with their corresponding $\mathrm{HOMO} / \mathrm{SOMO}$ and LUMO orbital diagrams and ESP explaining the electron rich nature. Here positive and negative spin is denoted by brown and green colour, respectively. And the blue and red colour of the ESP diagram indicates the electron deficient and electron rich character. To reduce the computational time we have replaced the bulky axial part by methyl groups. Structure optimization have been carried out using B3LYP/6-311g(d,p) and UB3LYP/6-311g(d,p) for spin paired and unpaired systems, respectively. The respective HOMO-LUMO levels were calculated by performing single-point energy calculations using B3LYP/6-311g(d,p) or UB3LYP/6-311g(dp) with bulk solvent $(\mathrm{MeCN})$ effects, approximated using integral equation formalism-polarizable continuum model (IEF-PCM). Calculated HOMO/LUMO for $\mathbf{4}^{+} \mathbf{B r}^{-}$are $-6.54 /-3.70$ and SOMO/LUMO for $\mathbf{4}^{\bullet \pm}$ are $4.24 /-1.75$.

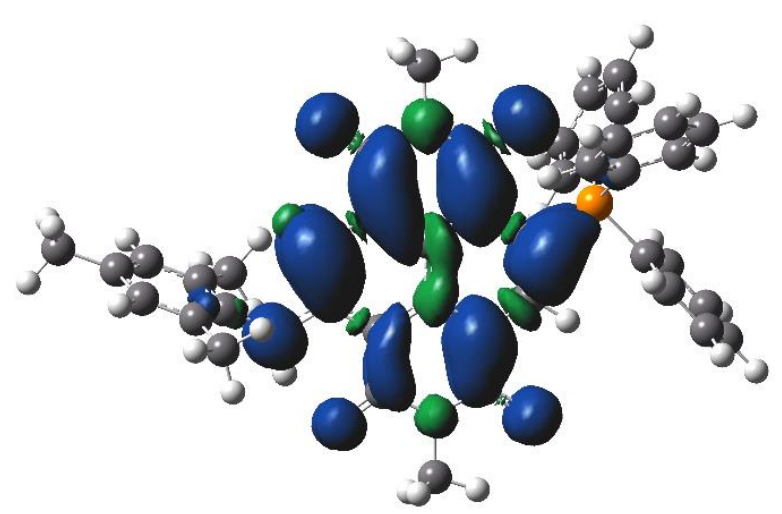

Figure S8b: Spin density plot of $\mathbf{4}^{\cdot \pm}$ showing the asymmetric distribution of the spin over the imide rings and the naphthalene rings. Also, note the large spin distribution over the $\mathrm{N}$ of the meistyl amine and the $\mathrm{O}$ adjacent to the phosphonium group. 

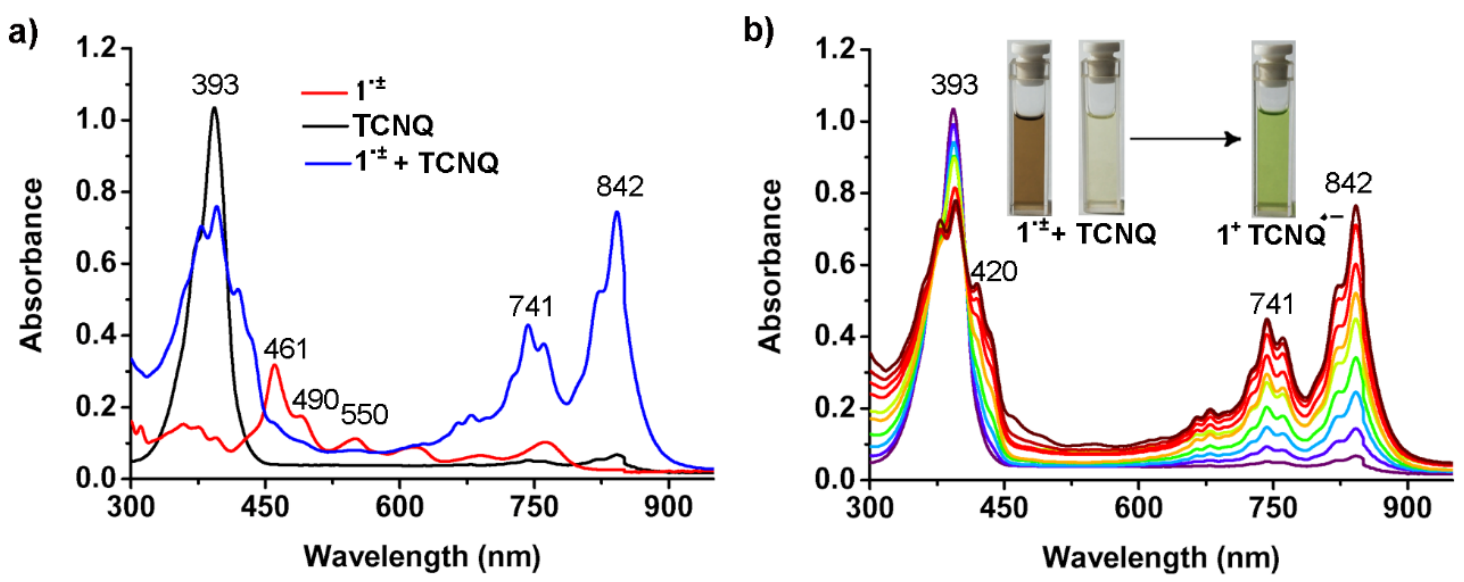

Figure S9. UV-vis-NIR spectrum of $\mathbf{1}^{{ }^{ \pm}}$, TCNQ and the mixture of $\mathbf{1}^{\cdot \pm}$ and TCNQ (a), and spectrum of TCNQ (in MeCN, $0.02 \mathrm{mM}$ ) with the gradual addition of $\mathbf{1}^{\bullet \pm}$ as the reducing agent (0 to 1.6 equivalents) with its corresponding coloured solutions $(0.1 \mathrm{mM})$.

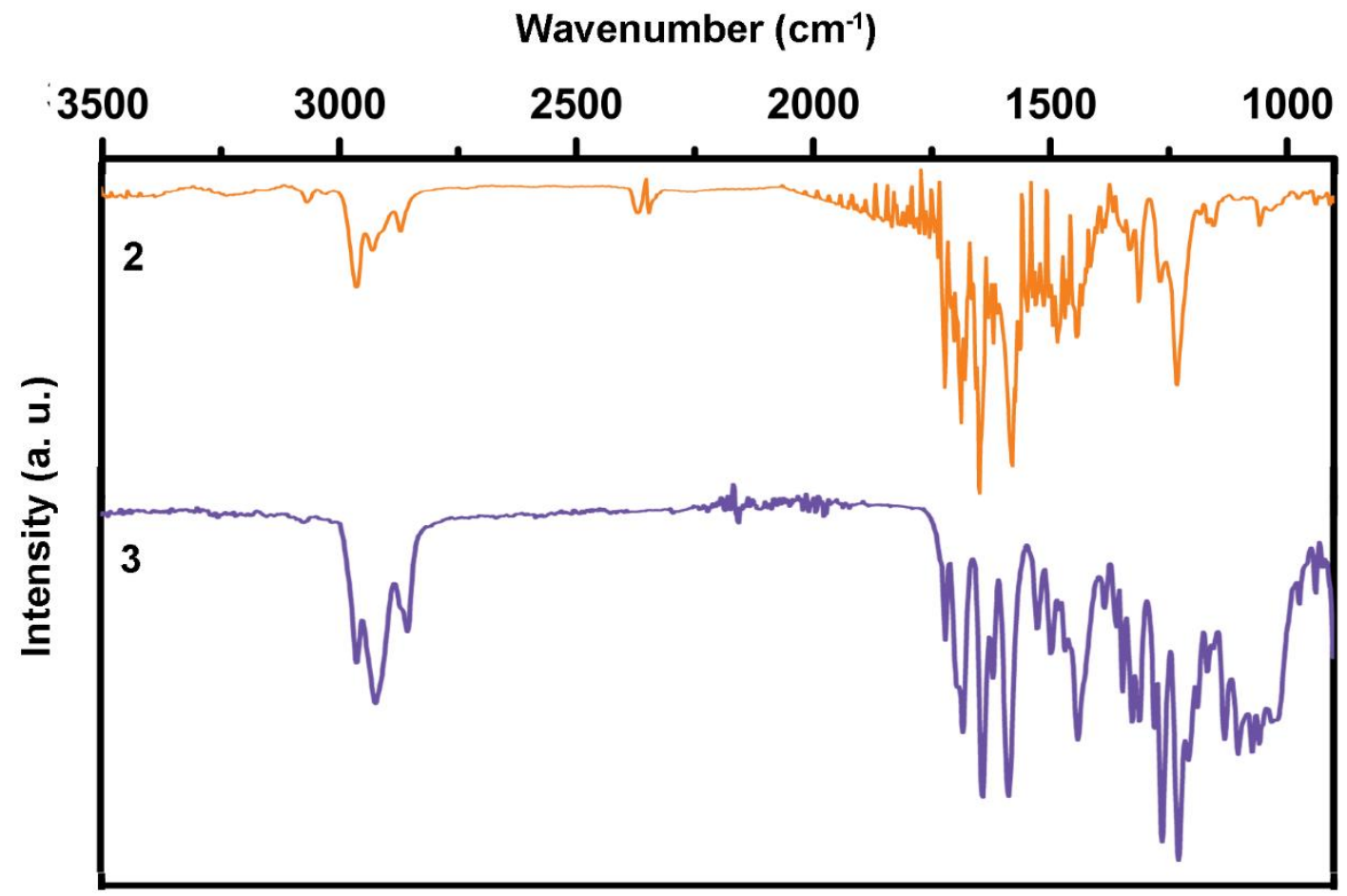

Figure S10: FTIR spectra of compounds 2 and 3. 


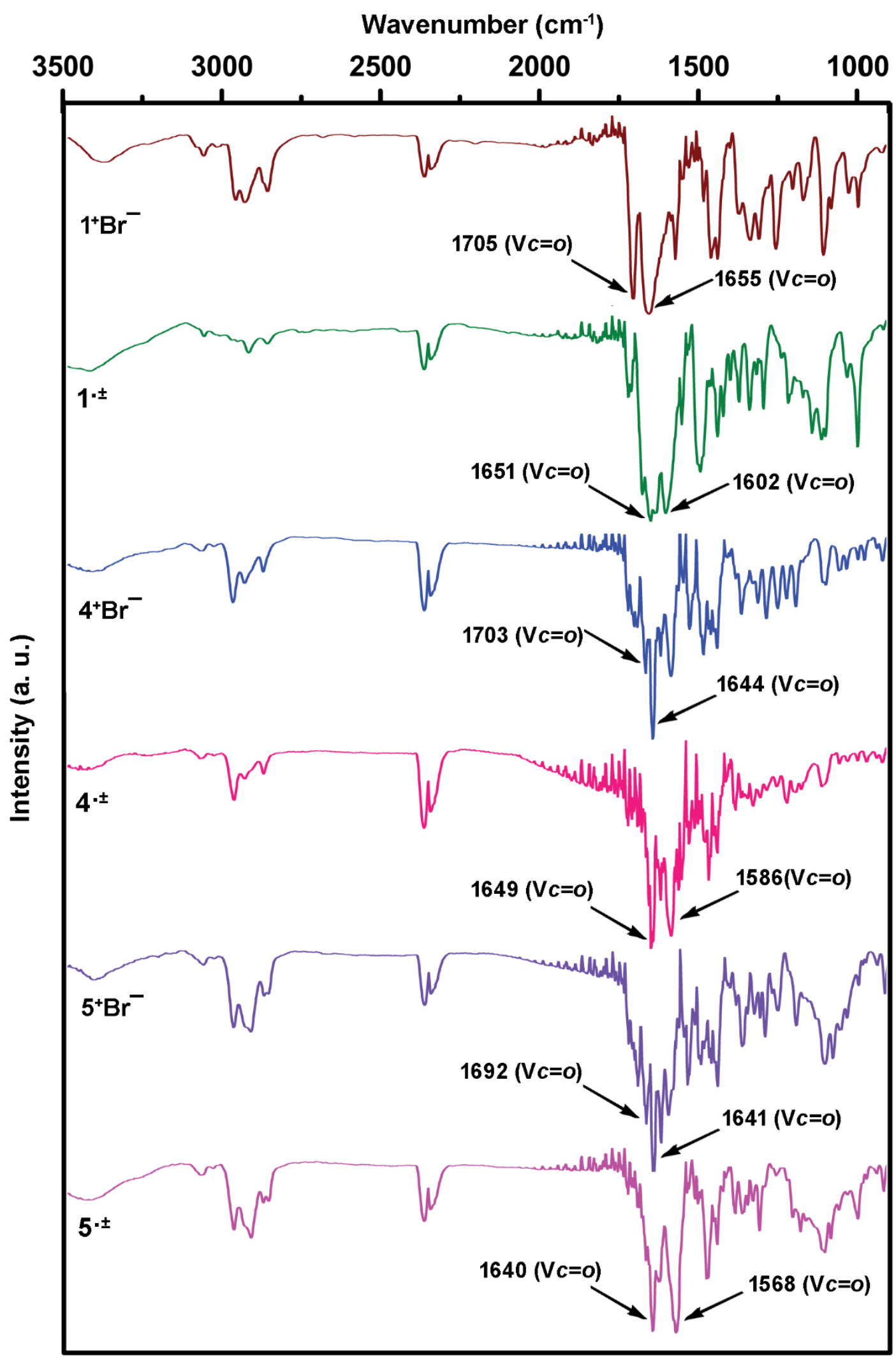

Figure S11: FTIR spectra of compounds $\mathbf{1}^{+} \mathbf{B r}^{-}, 4^{+} \mathbf{B r}^{-}, \mathbf{5}^{+} \mathbf{B r}^{-}$and their corresponding radicals $\mathbf{1}^{\cdot \pm}$, $4^{\cdot \pm}$ and $5^{\cdot \pm}$. 


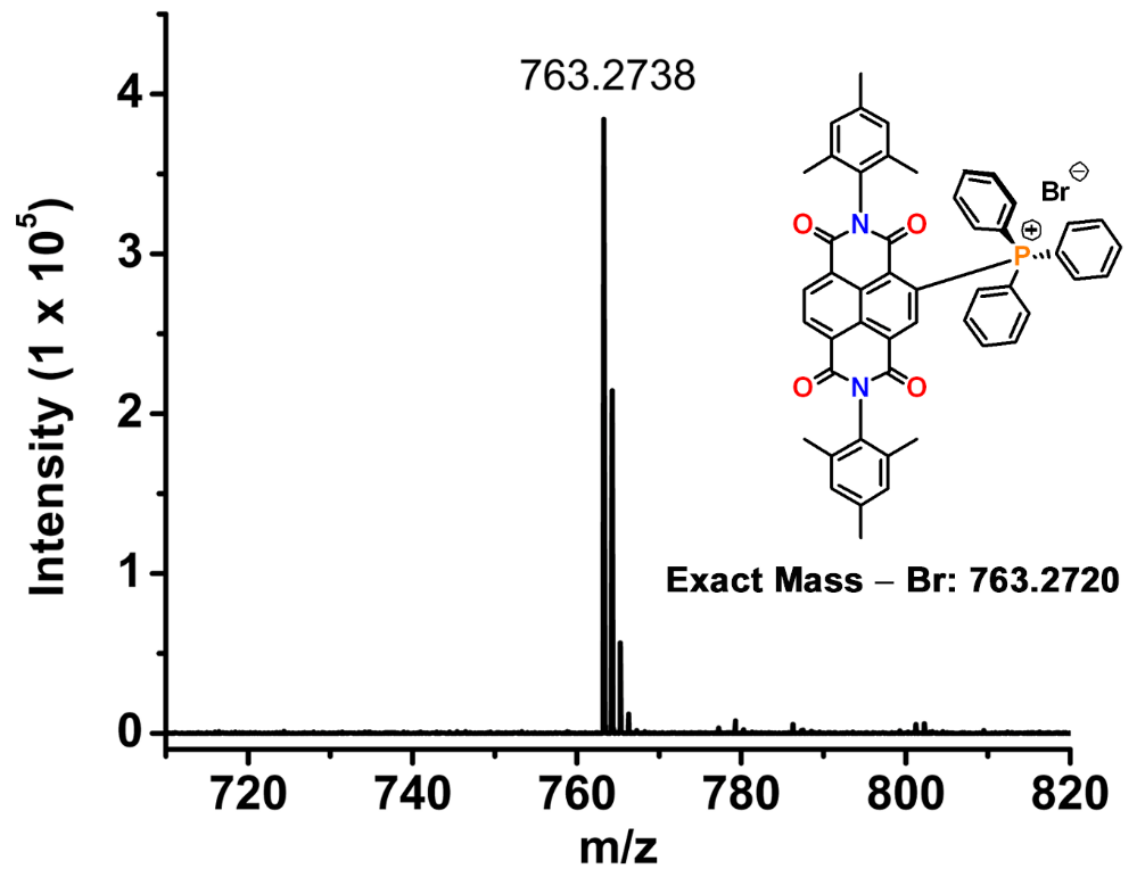

Figure S12: Mass spectrum of compound $\mathbf{1}^{+} \mathbf{B r}^{-}$.

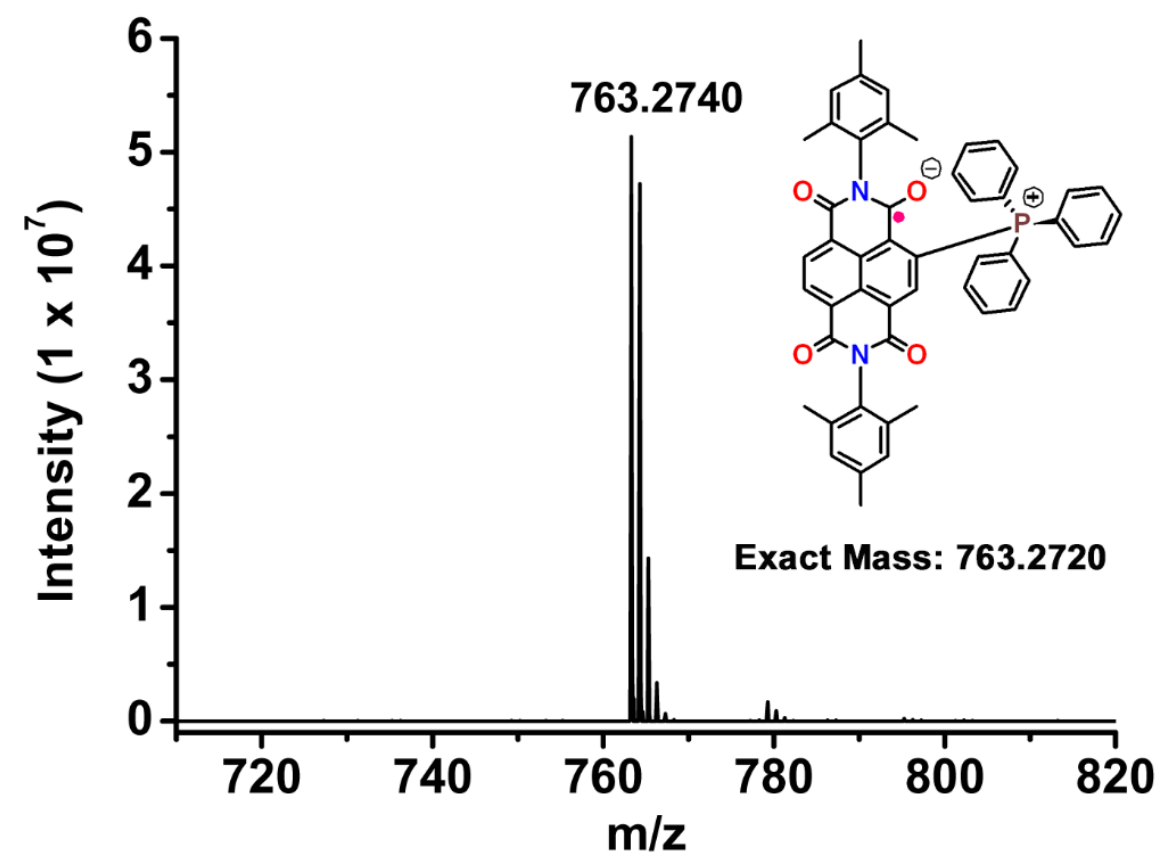

Figure S13: Mass spectrum of compound $\mathbf{1}^{\cdot \pm}$. 


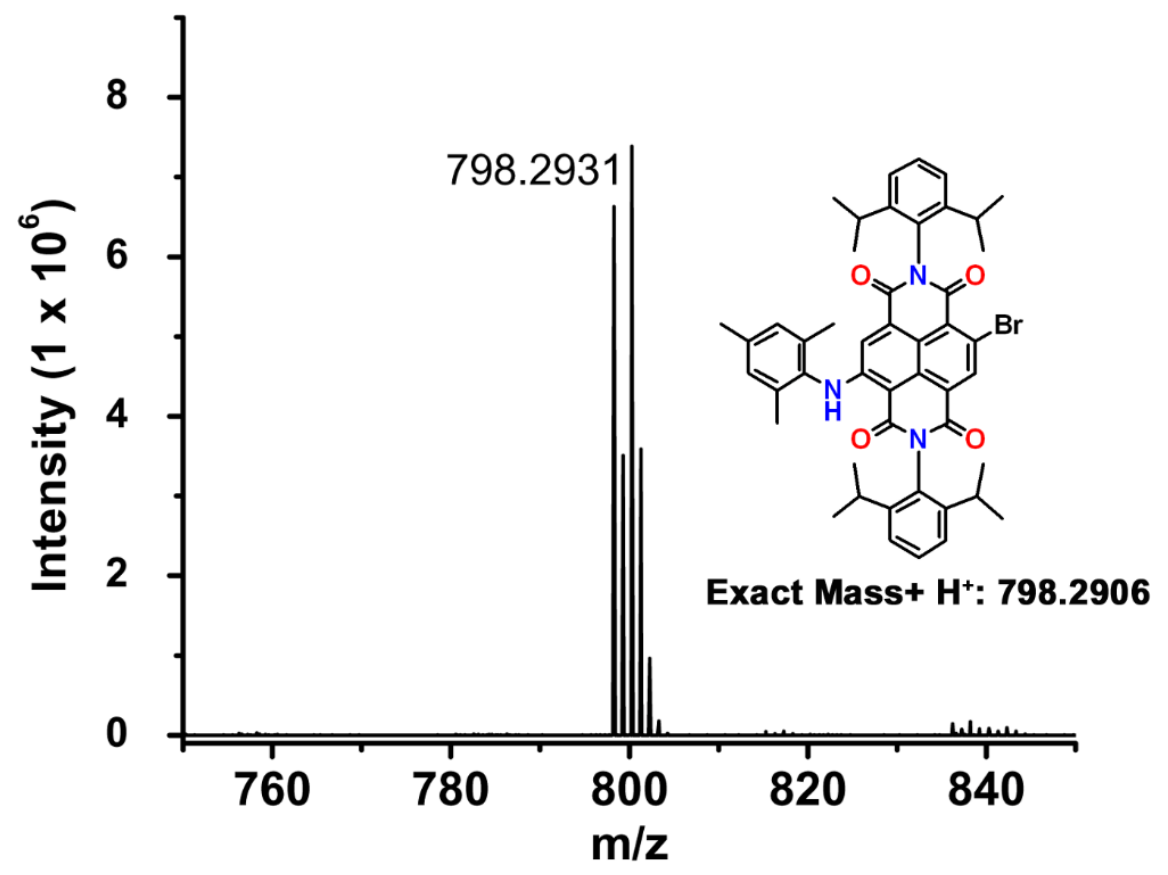

Figure S14: Mass spectrum of compound 2.

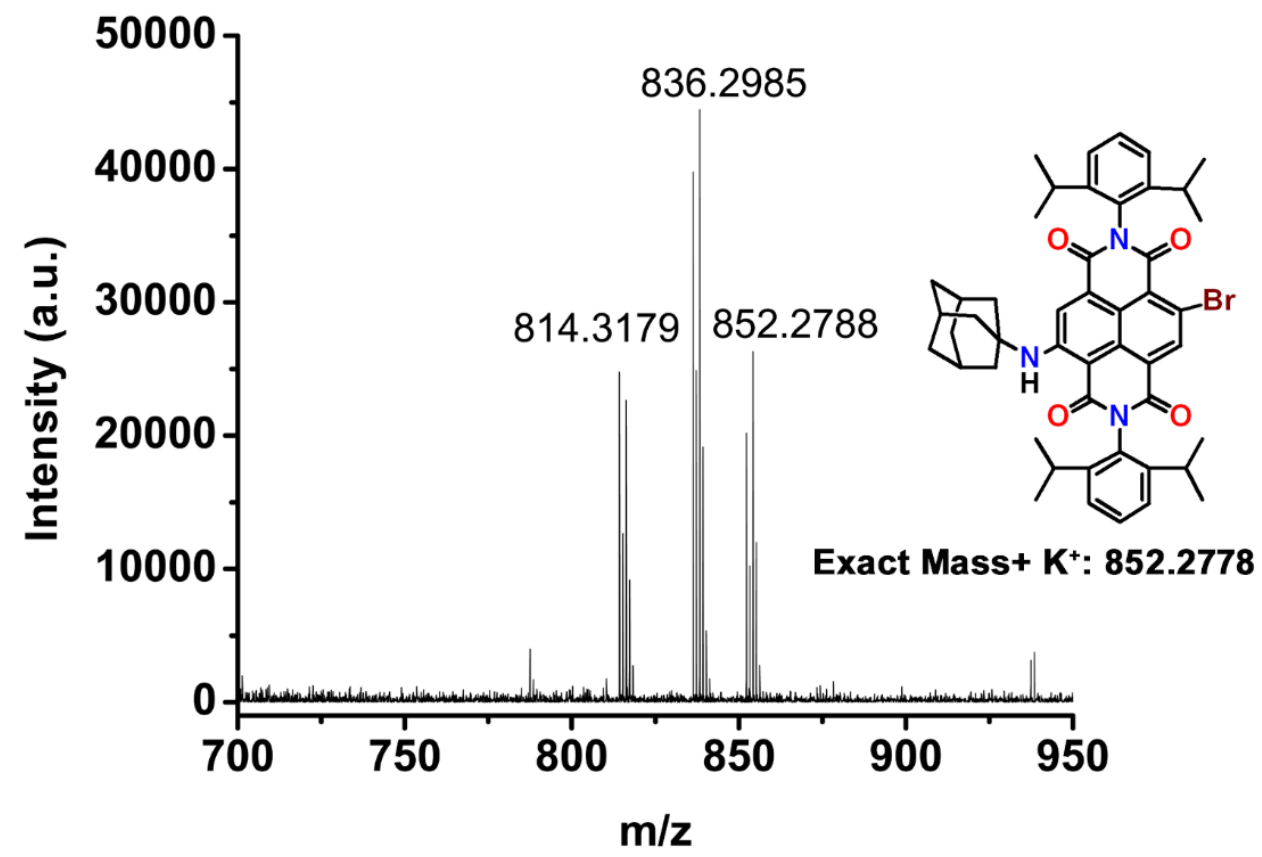

Figure S15: Mass spectrum of compound 3. 


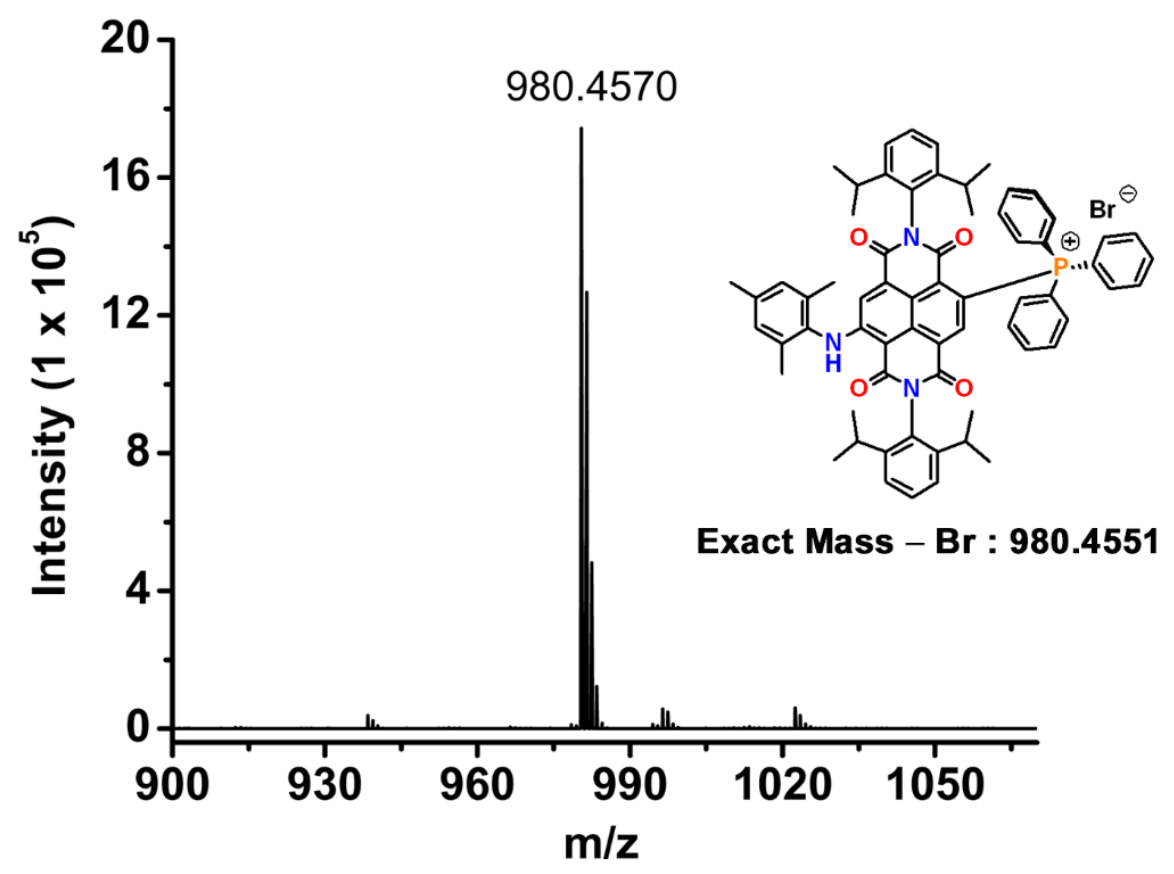

Figure S16: Mass spectrum of compound $4^{+} \mathrm{Br}^{-}$.

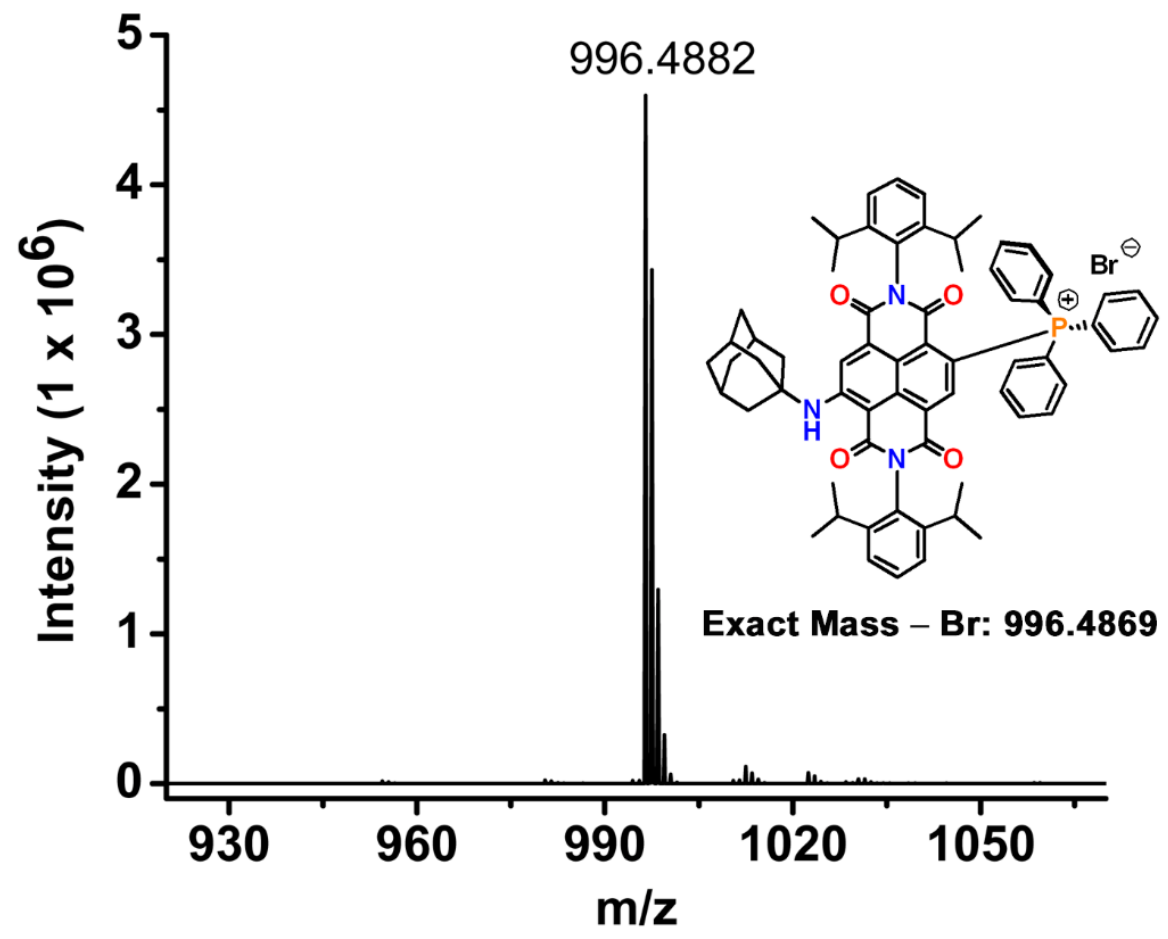

Figure S17: Mass spectrum of compound $\mathbf{5}^{+} \mathrm{Br}^{-}$. 


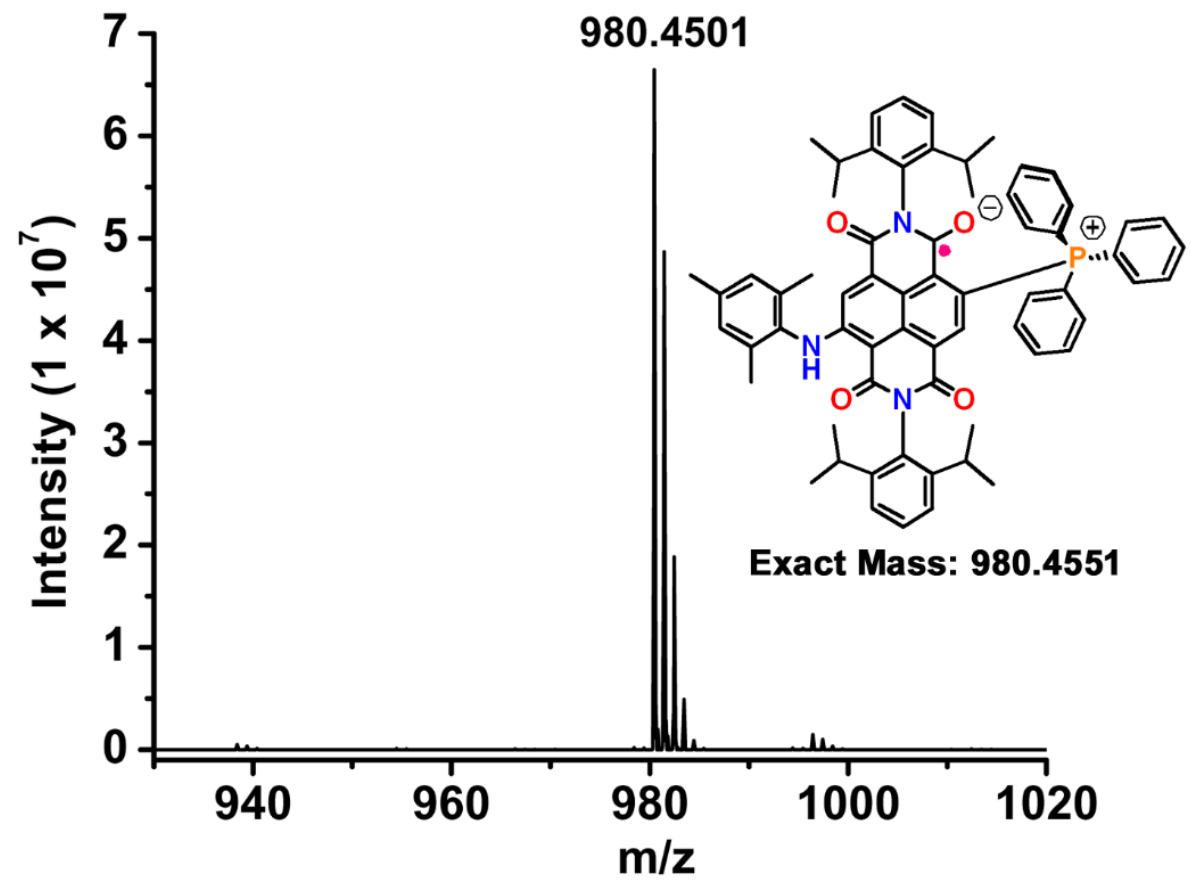

Figure S18: Mass spectrum of compound $\mathbf{4}^{\cdot \pm}$.

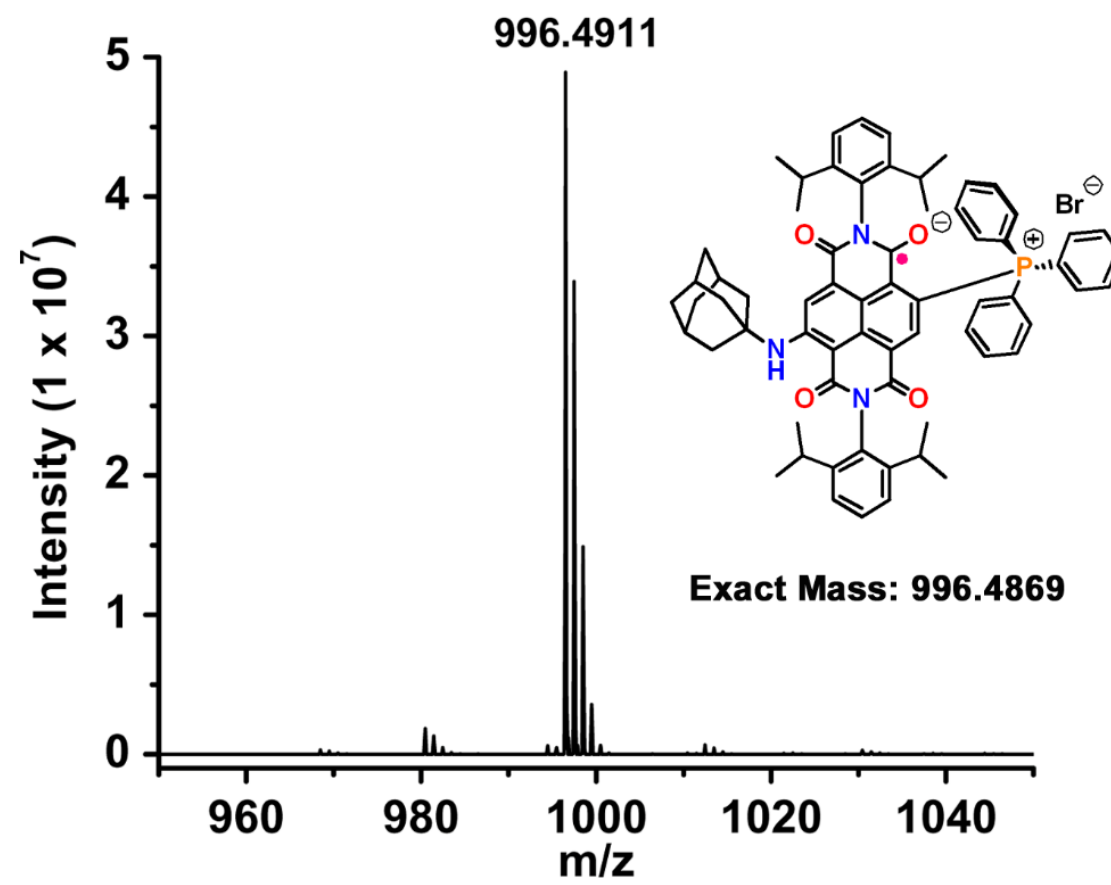

Figure S19: Mass spectrum of compound 5•*. 


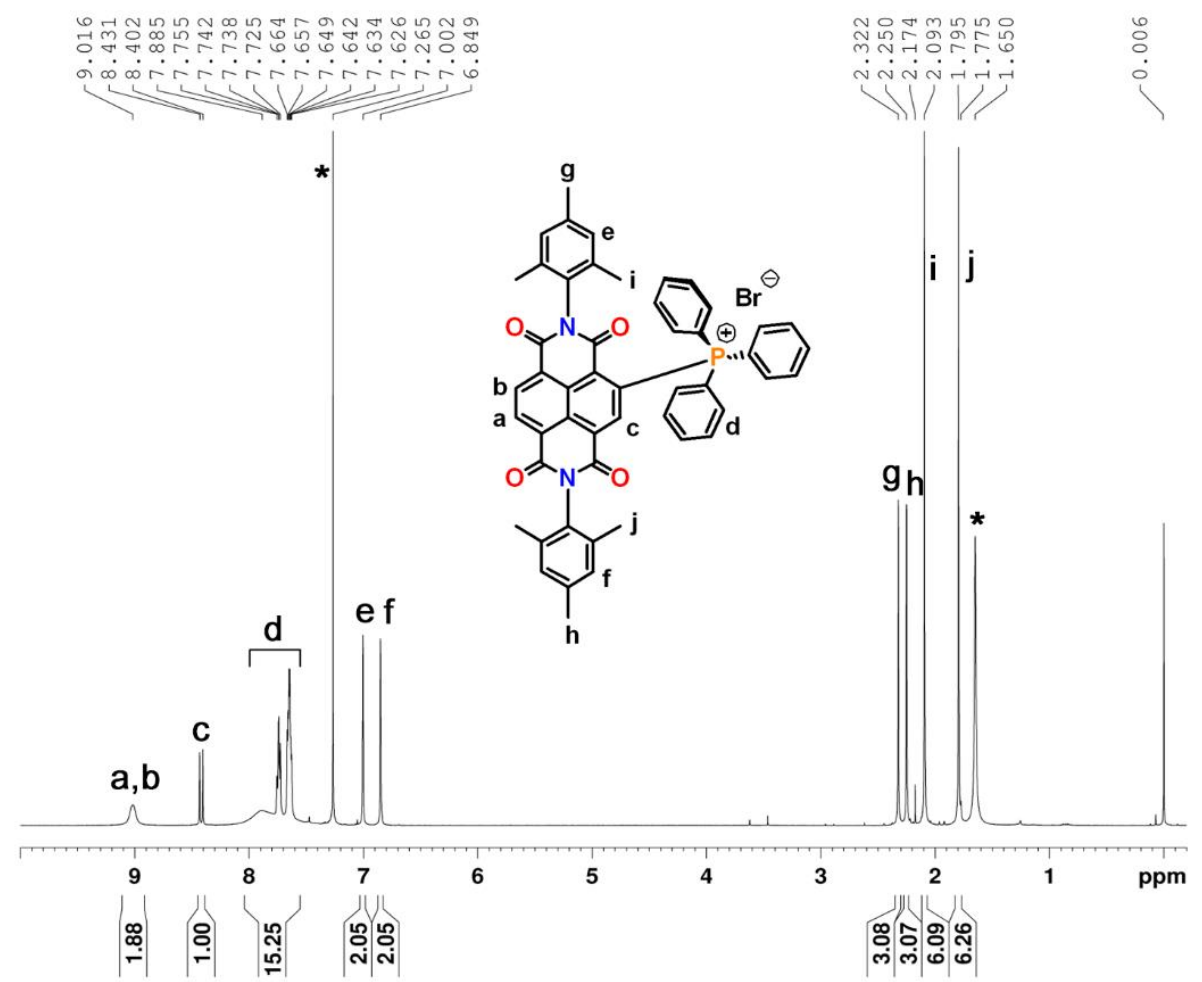

Figure S20: $500 \mathrm{MHz}{ }^{1} \mathrm{H}$ NMR spectrum of $\mathbf{1}^{+} \mathbf{B r}^{-}$in $\mathrm{CDCl}_{3}$ at $\mathrm{RT}$.

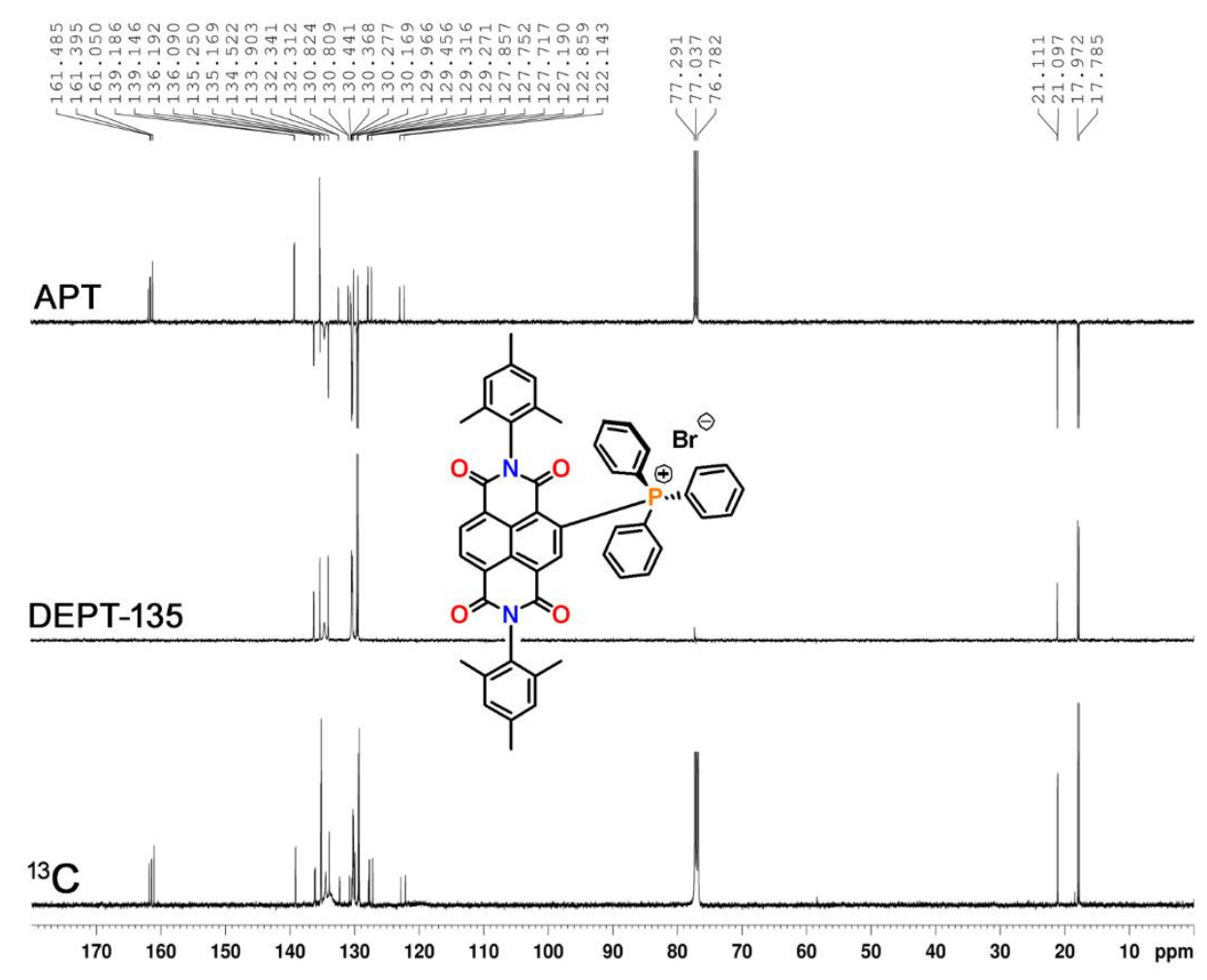

Figure S21: $125 \mathrm{MHz}{ }^{13} \mathrm{C}$ NMR spectrum of $\mathbf{1}^{+} \mathbf{B r}^{-}$in $\mathrm{CDCl}_{3}$ at $\mathrm{RT}$. 


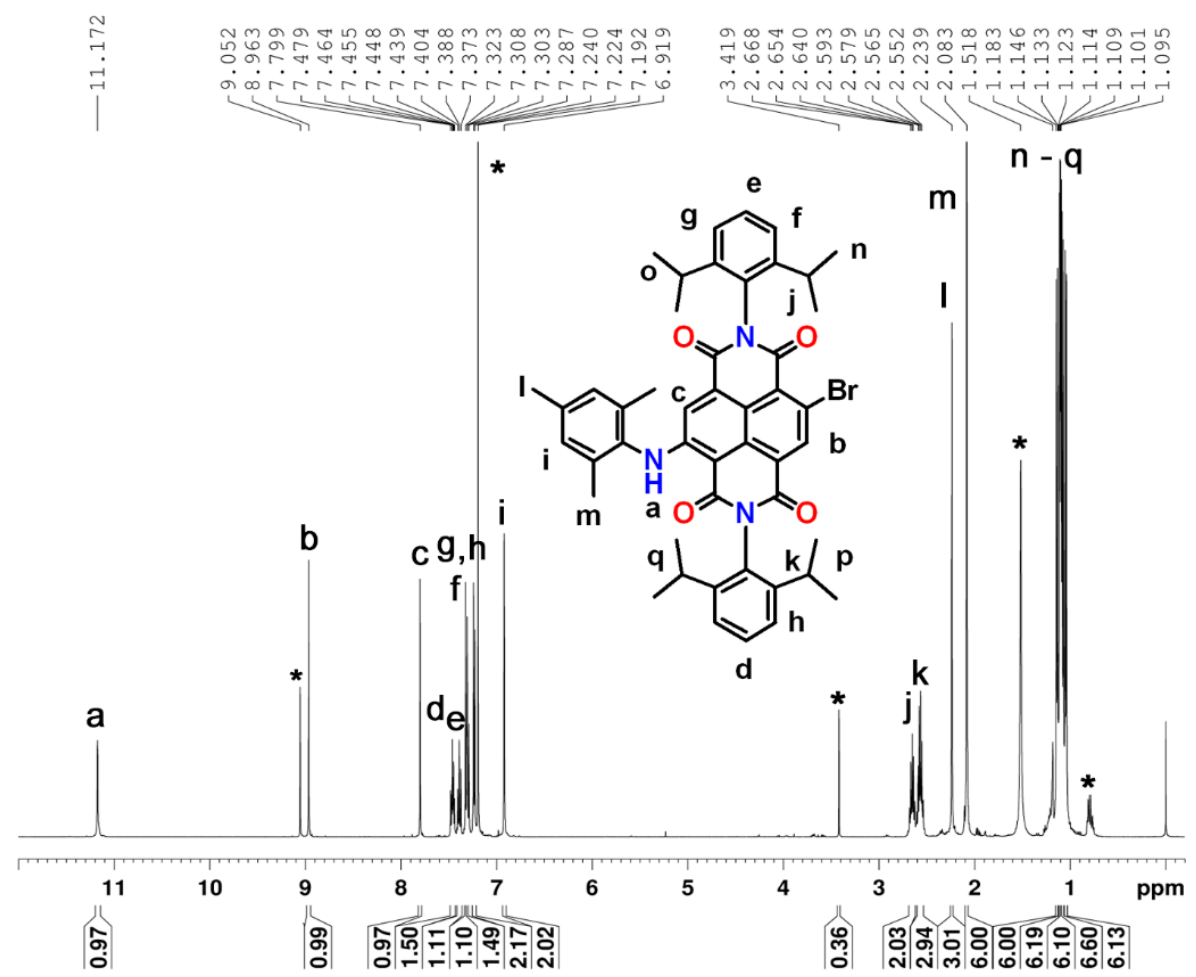

Figure S22: $500 \mathrm{MHz}{ }^{1} \mathrm{H}$ NMR spectrum of 2 in $\mathrm{CDCl}_{3}$ at RT.

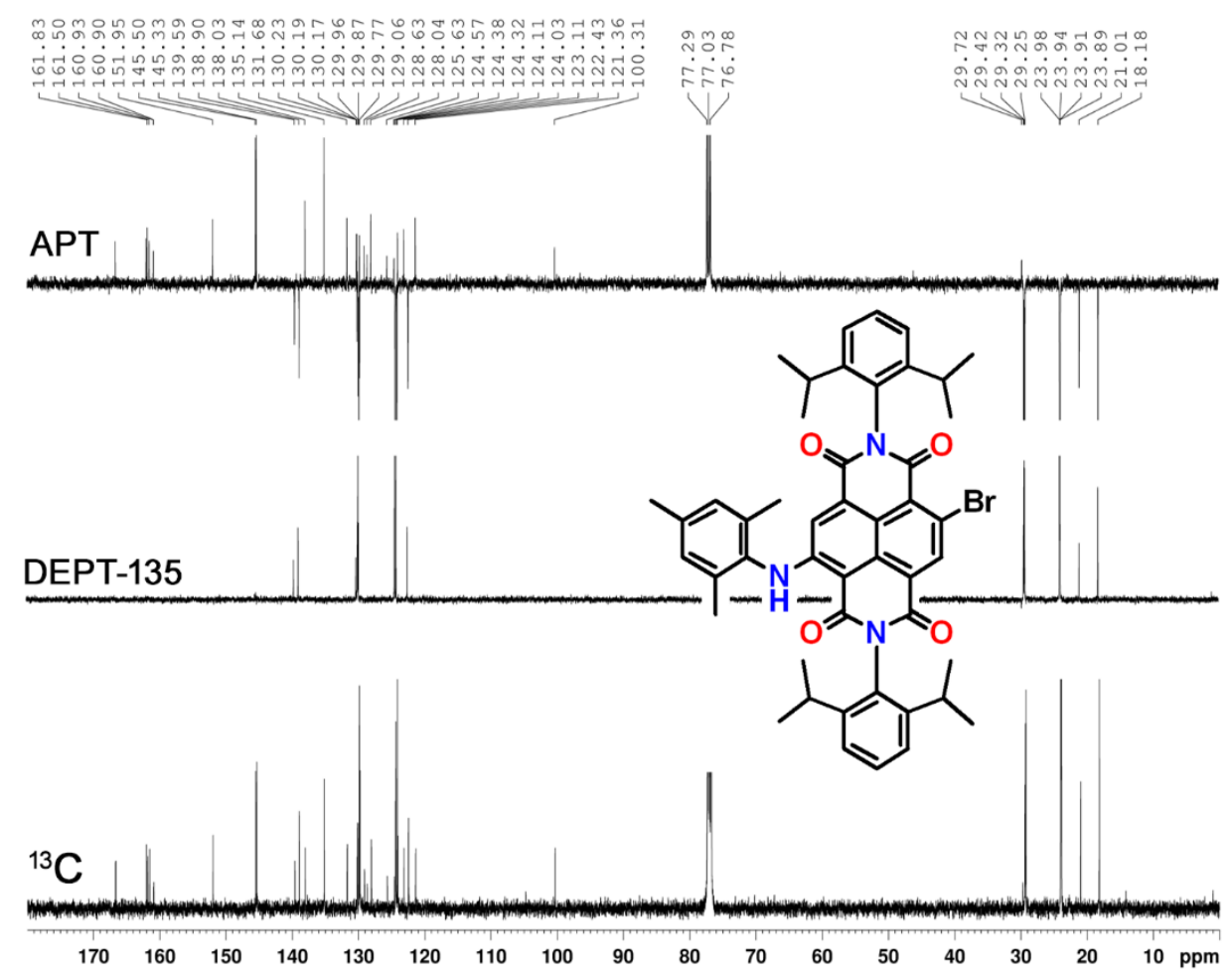

Figure S23: $125 \mathrm{MHz}{ }^{13} \mathrm{C}$ NMR spectrum of 2 in $\mathrm{CDCl}_{3}$ at $\mathrm{RT}$. 


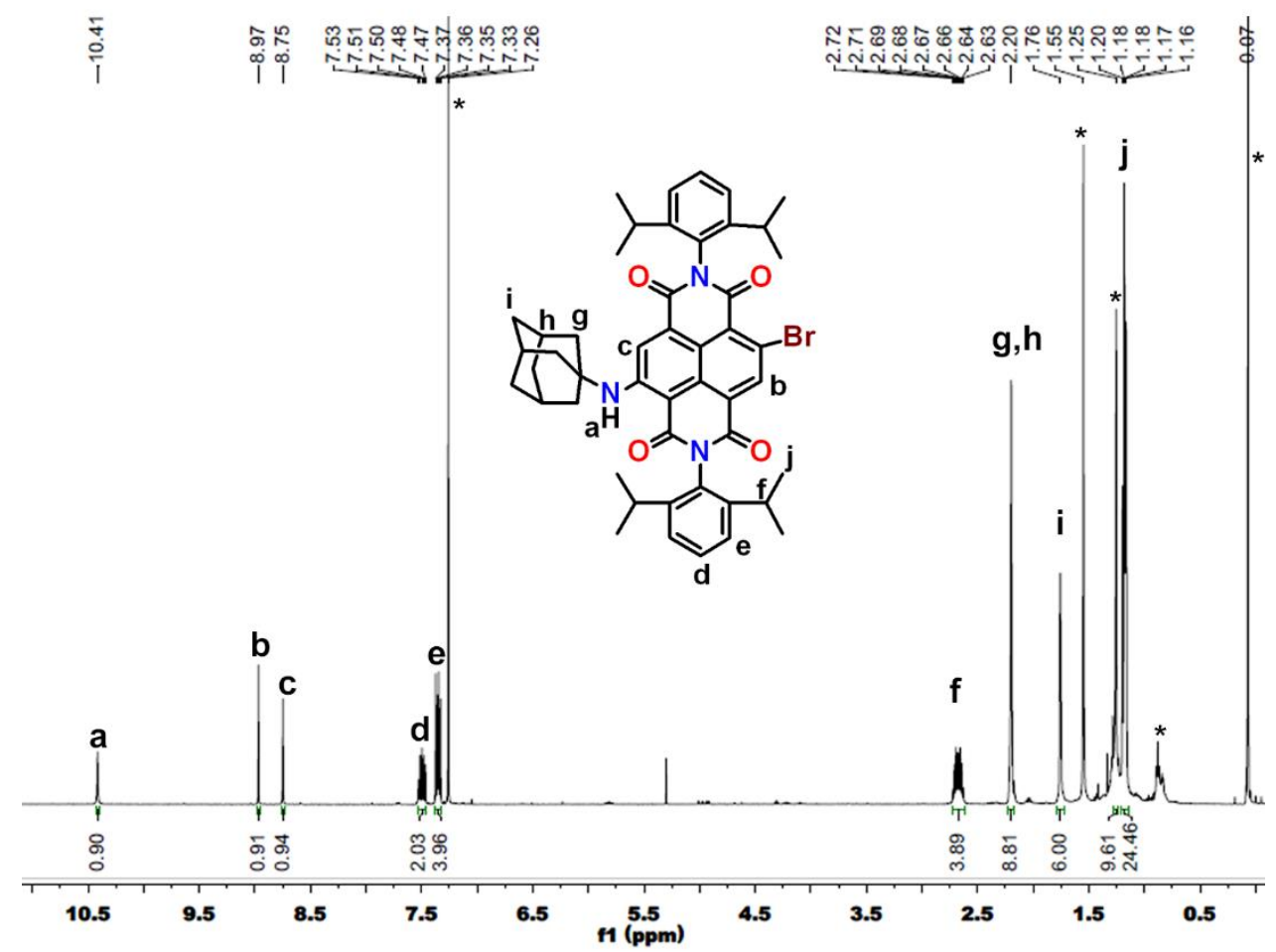

Figure S24: $500 \mathrm{MHz}{ }^{1} \mathrm{H}$ NMR spectrum of 3 in $\mathrm{CDCl}_{3}$ at RT.

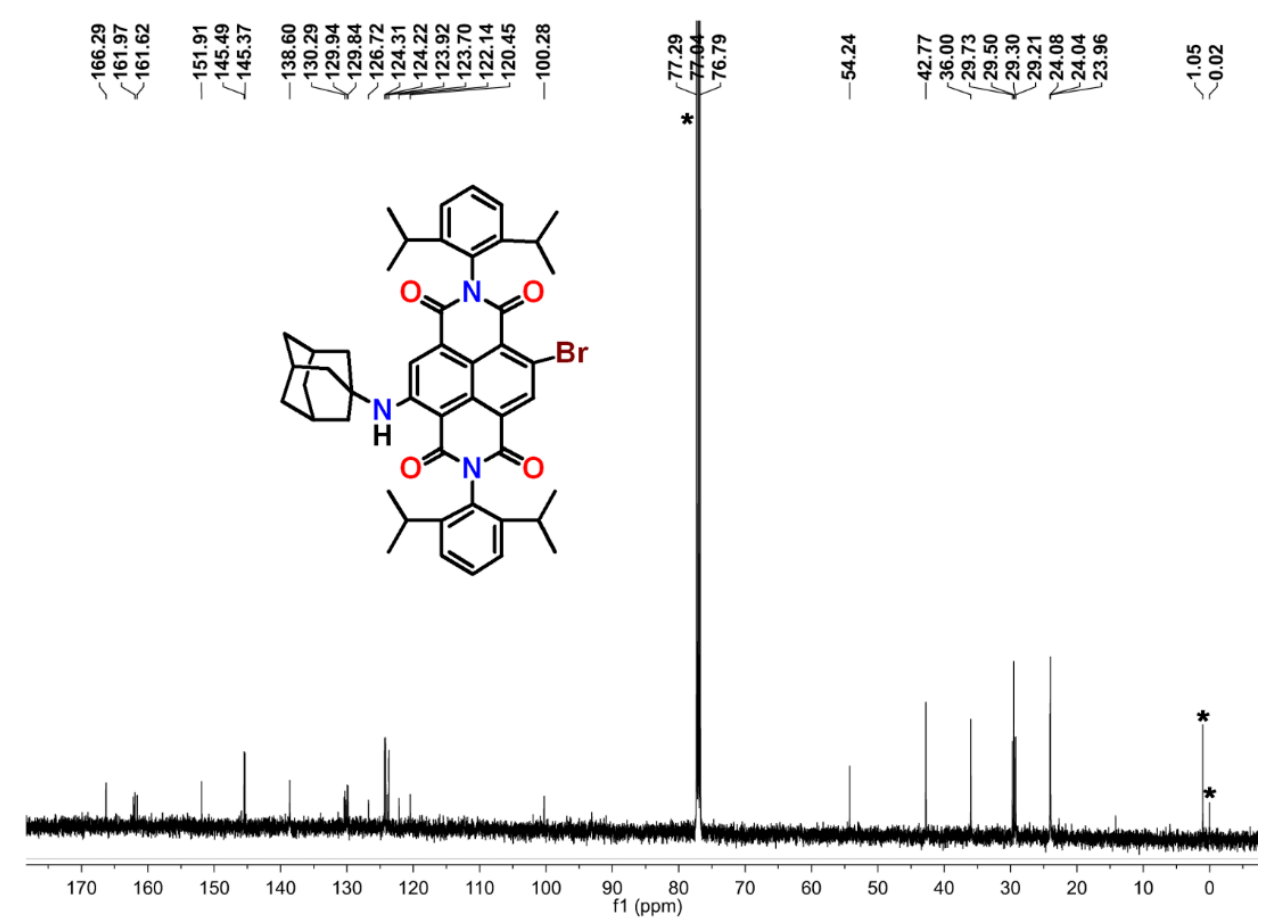

Figure S25: $125 \mathrm{MHz}{ }^{13} \mathrm{C}$ NMR spectrum of 3 in $\mathrm{CDCl}_{3}$ at $\mathrm{RT}$. 


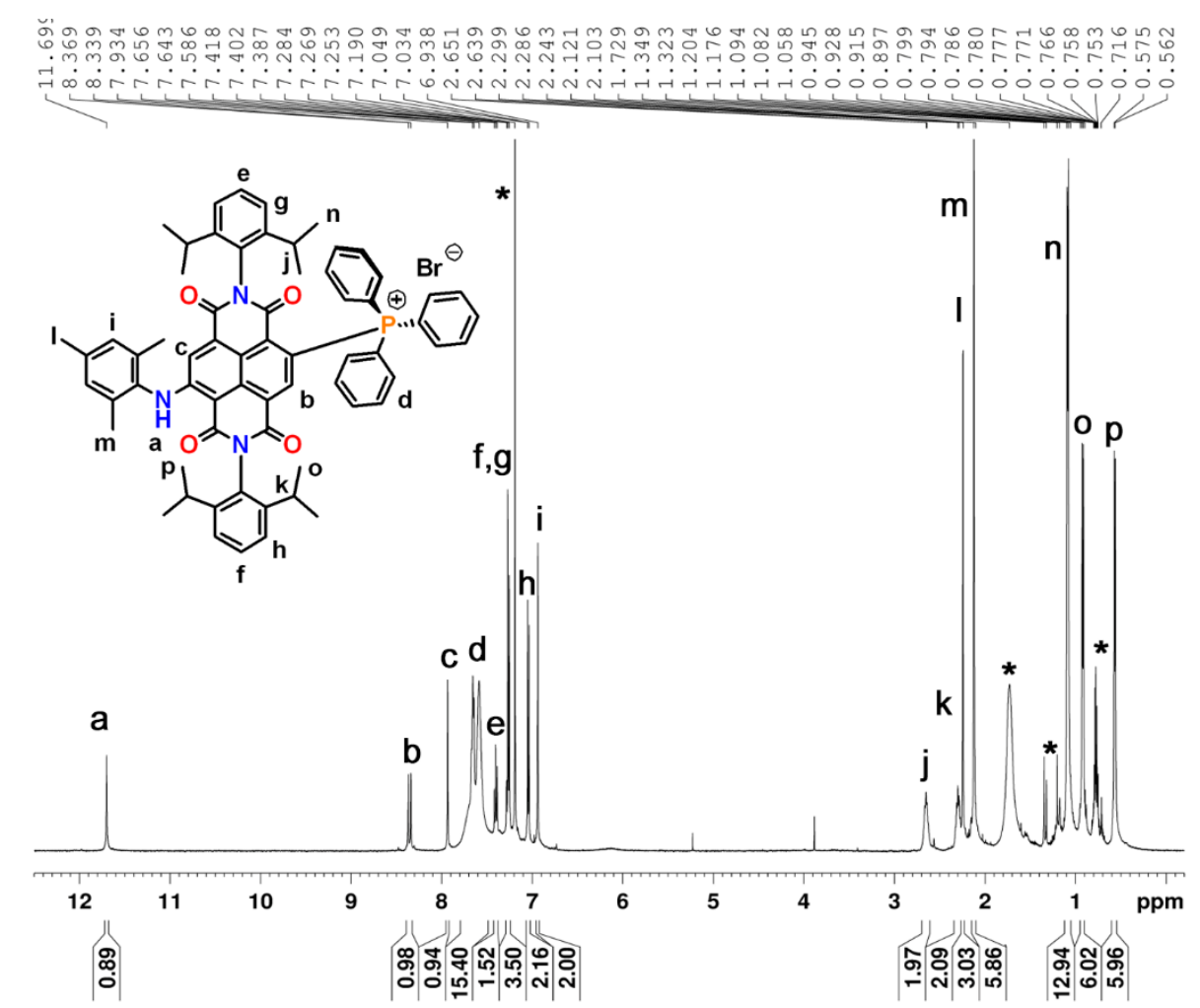

Figure S26: $500 \mathrm{MHz}{ }^{1} \mathrm{H} \mathrm{NMR}$ spectrum of $\mathbf{4}^{+} \mathbf{B r}^{-}$in $\mathrm{CDCl}_{3}$ at $\mathrm{RT}$.

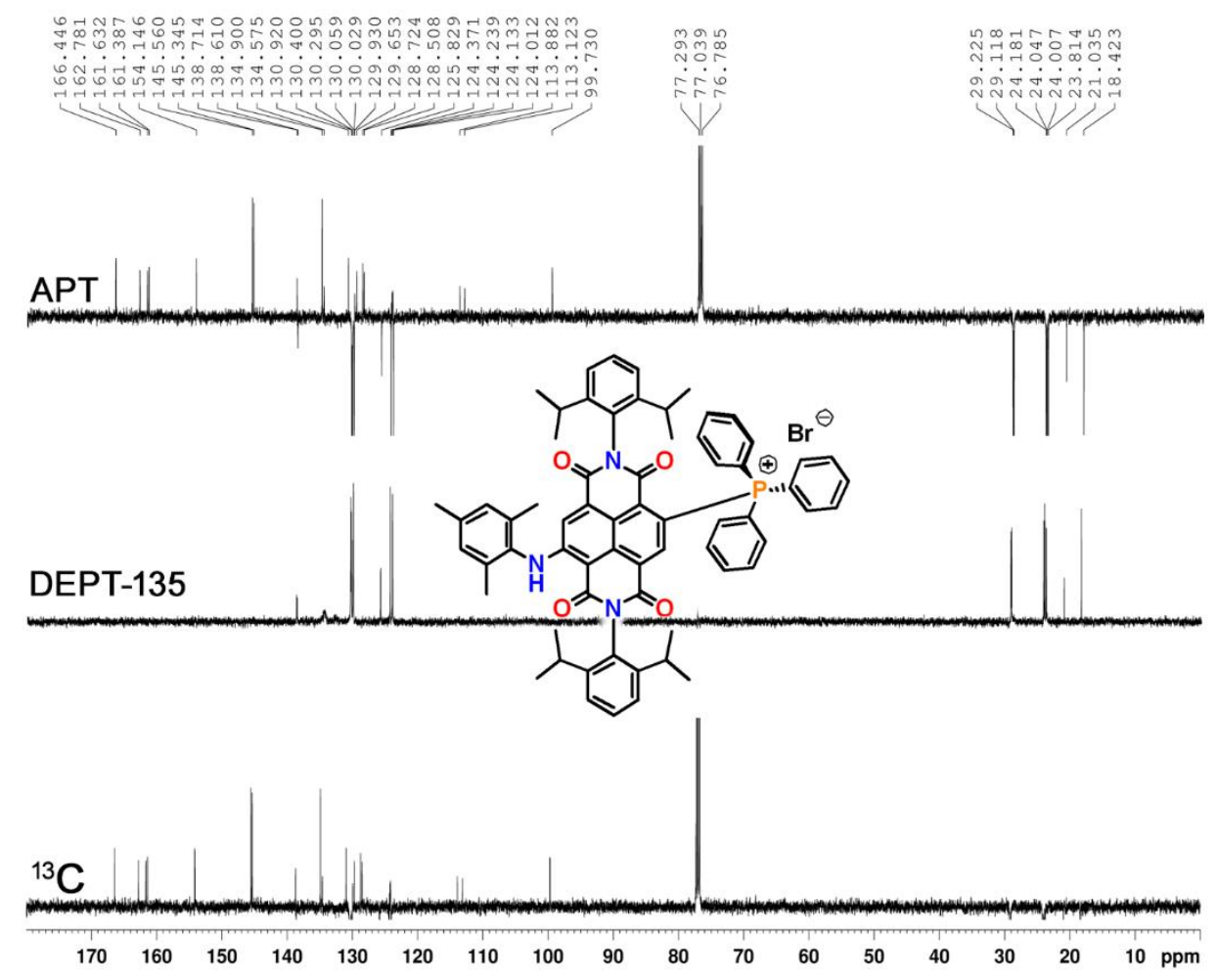

Figure S27: $125 \mathrm{MHz}{ }^{13} \mathrm{C}$ NMR spectrum of $\mathbf{4}^{+} \mathbf{B r}^{-}$in $\mathrm{CDCl}_{3}$ at $\mathrm{RT}$. 


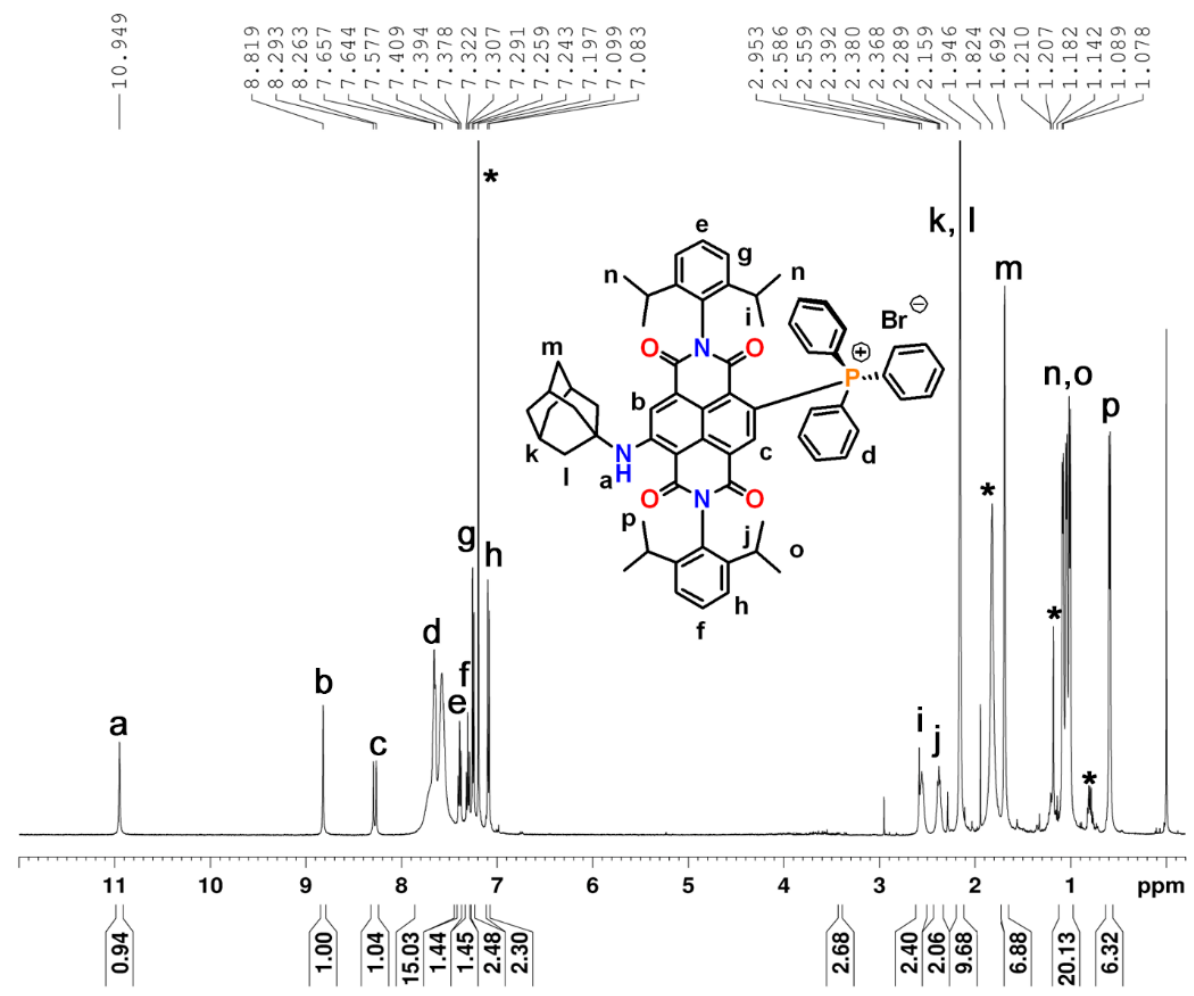

Figure S28: $500 \mathrm{MHz}{ }^{1} \mathrm{H}$ NMR spectrum of $\mathbf{5}^{+} \mathbf{B r}^{-}$in $\mathrm{CDCl}_{3}$ at RT.

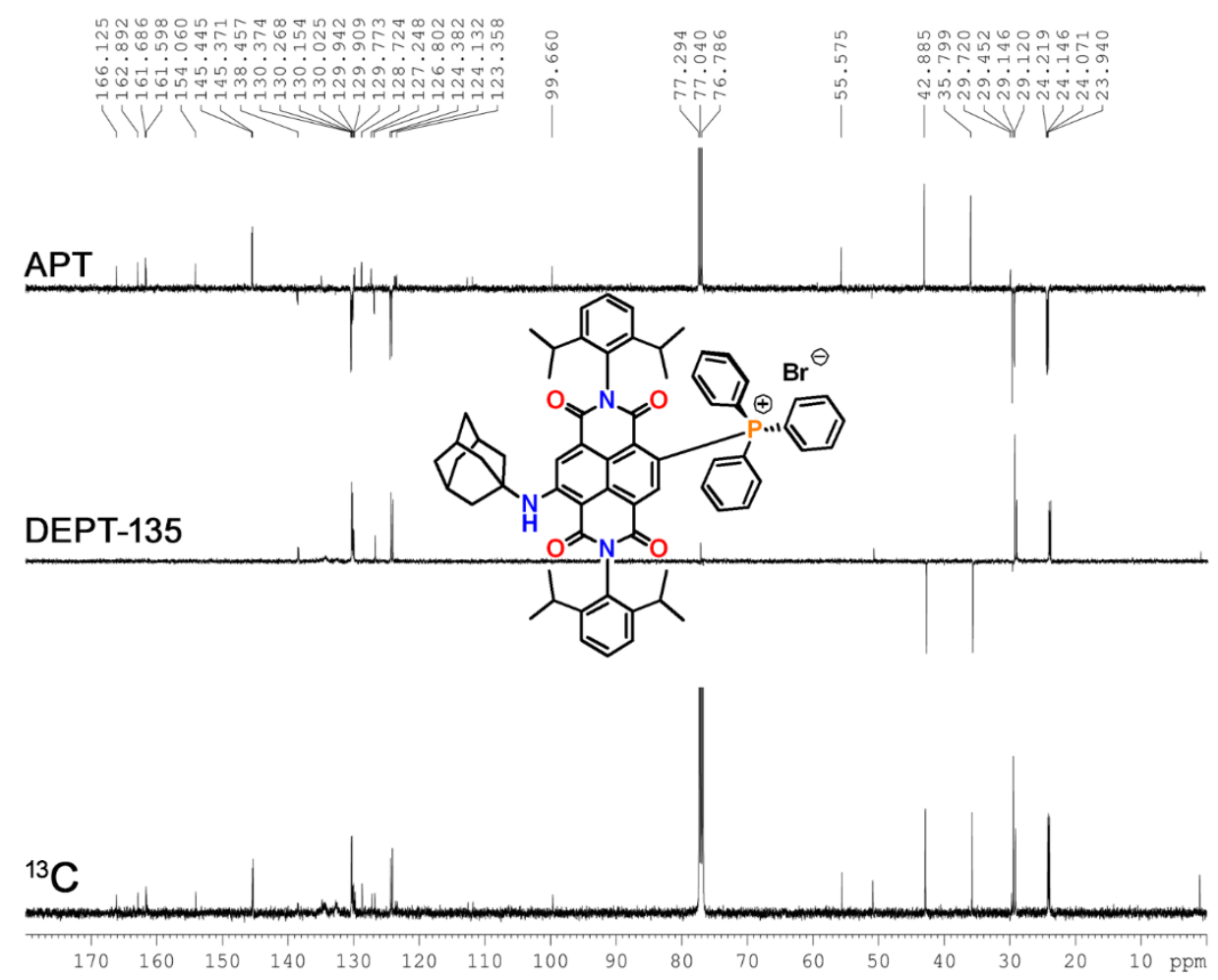

Figure S29: $125 \mathrm{MHz}{ }^{13} \mathrm{C}$ NMR spectrum of $\mathbf{5}^{+} \mathbf{B r}^{-}$in $\mathrm{CDCl}_{3}$ at RT. 

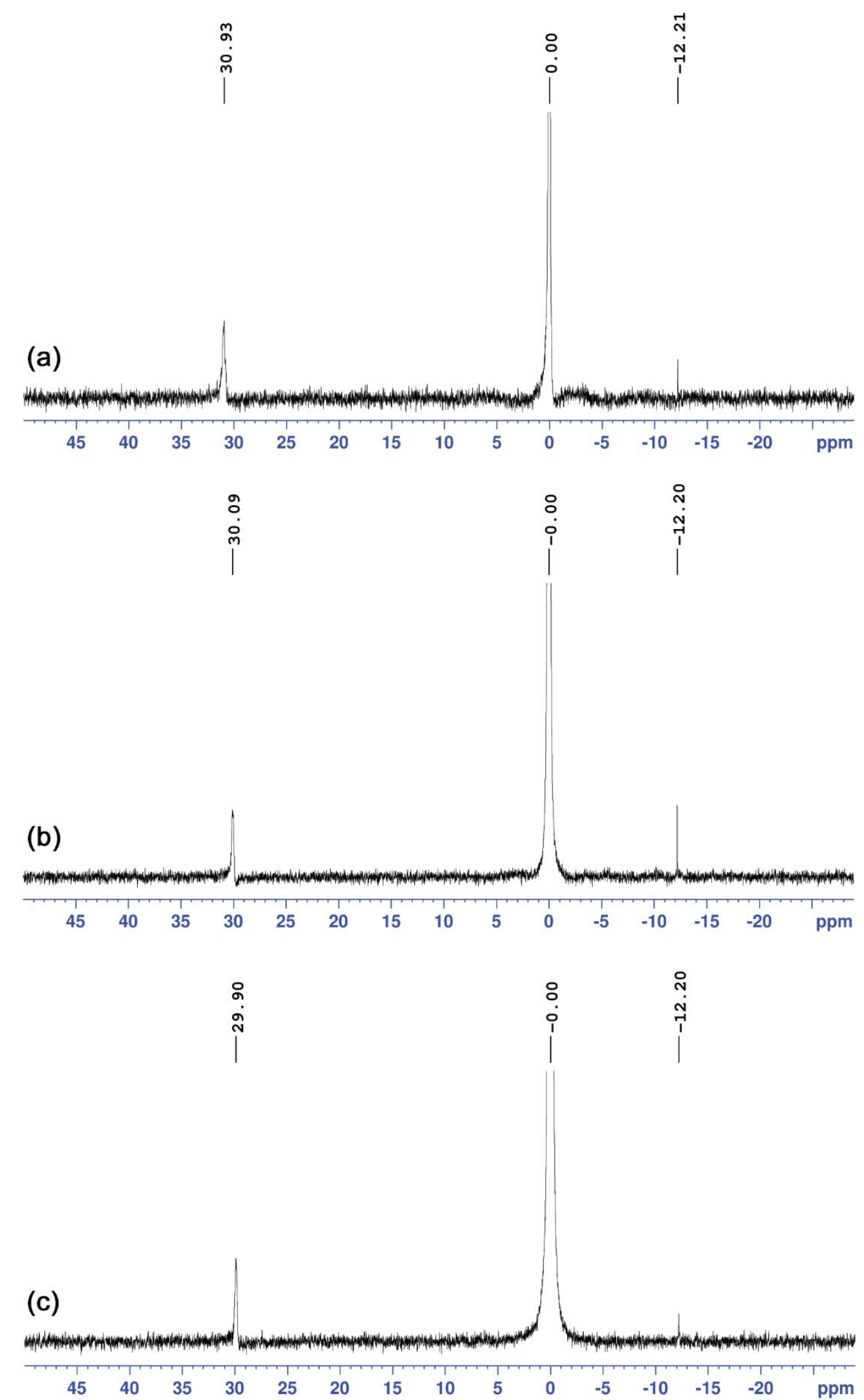

Figure S30: $202 \mathrm{MHz}{ }^{31} \mathrm{P}$ spectrum of $\mathbf{1}^{+} \mathbf{B r}^{-}$(a), $\mathbf{4}^{+} \mathbf{B r}^{-}$(b), and $\mathbf{5}^{+} \mathbf{B r}^{-}$in $\mathrm{CDCl}_{3}$ at room temperature. 
Table S4: Crystal data and structure refinement parameters for $\mathbf{1}^{+} \mathbf{B r}^{-}$and $\mathbf{1}^{\cdot \pm}$.

\begin{tabular}{|c|c|c|}
\hline & $\mathrm{1}^{+} \mathrm{Br}^{-}$ & $1^{\cdot \pm}$ \\
\hline Empirical formula & $\mathrm{C}_{50} \mathrm{H}_{40} \mathrm{~N}_{2} \mathrm{O}_{4} \mathrm{PBr}$ & $\begin{array}{l}\mathrm{C}_{50} \mathrm{H}_{40} \mathrm{~N}_{2} \mathrm{O}_{4} \mathrm{P} . \\
\left(\mathrm{CH}_{2} \mathrm{Cl}_{2}\right)\end{array}$ \\
\hline Formula weight & 843.71 & 842.77 \\
\hline Temperature (K) & 100 & 100 \\
\hline Wavelength $(\AA)$ & 0.71073 & 0.71073 \\
\hline Crystal system & Triclinic & Monoclinic \\
\hline Space group & $P \overline{1}$ & P 21/n \\
\hline \multicolumn{3}{|l|}{ Unit cell dimensions } \\
\hline$a$ & $12.4682(11) \AA$ & $12.7739(7) \AA$ \\
\hline$b$ & $12.5666(12) \AA$ & $23.9332(14) \AA$ \\
\hline$c$ & $16.7376(17) \AA$ & $15.5828(2) \AA$ \\
\hline$\alpha$ & $77.848(6)^{\circ}$ & 90 \\
\hline$\beta$ & $69.960(5)^{\circ}$ & $107.641(2)^{\circ}$ \\
\hline$\gamma$ & $86.936(5)^{\circ}$ & 90 \\
\hline Volume $\left(\AA^{3}\right)$ & $2408.0(4) \AA^{3}$ & $4539.9(4) \AA^{3}$ \\
\hline $\mathrm{Z}$ & 2 & 2 \\
\hline $\begin{array}{l}\text { Absorption } \\
\text { coefficient }\end{array}$ & $0.928 \mathrm{~mm}^{-1}$ & $0.224 \mathrm{~mm}^{-1}$ \\
\hline $\mathrm{F}(000)$ & 872 & 1772 \\
\hline Theta range & 2.32 to 23.76 & $2.186-28.332$ \\
\hline Completeness & $97.5 \%$ & $99.7 \%$ \\
\hline $\begin{array}{l}\text { Goodness-of-fit on } \\
\mathrm{F}^{2}\end{array}$ & 0.955 & 1.021 \\
\hline R(reflections) & $0.0826(4733)$ & $0.0646(10027)$ \\
\hline wR2(reflections) & $0.2206(12056)$ & $0.1612(11281)$ \\
\hline
\end{tabular}


Table S5: Theoretical calculation details of $\mathbf{4}^{+} \mathbf{B r}^{-}$:

\begin{tabular}{|c|c|c|c|c|}
\hline \multirow{2}{*}{$\begin{array}{l}\text { Center } \\
\text { Number }\end{array}$} & \multirow{2}{*}{$\begin{array}{l}\text { Atomic } \\
\text { Number }\end{array}$} & \multicolumn{3}{|c|}{ Coordinates (Angstroms) } \\
\hline & & $\mathrm{X}$ & $\mathrm{Y}$ & Z \\
\hline $\mathrm{C}$ & 6 & 3.081428 & -0.713169 & 0.085809 \\
\hline $\mathrm{C}$ & 6 & 3.405472 & 0.686880 & 0.023782 \\
\hline $\mathrm{C}$ & 6 & 2.332151 & 1.620796 & 0.002475 \\
\hline $\mathrm{C}$ & 6 & 1.000158 & 1.157415 & 0.031962 \\
\hline $\mathrm{C}$ & 6 & 0.699633 & -0.234365 & 0.092188 \\
\hline $\mathrm{C}$ & 6 & 1.790856 & -1.152908 & 0.116875 \\
\hline $\mathrm{C}$ & 6 & -0.082682 & 2.059902 & -0.003483 \\
\hline $\mathrm{C}$ & 6 & -1.389763 & 1.601098 & 0.009716 \\
\hline $\mathrm{C}$ & 6 & -1.695531 & 0.231909 & 0.080300 \\
\hline $\mathrm{C}$ & 6 & -0.625965 & -0.688981 & 0.125925 \\
\hline $\mathrm{C}$ & 6 & -0.888438 & -2.149418 & 0.228846 \\
\hline $\mathrm{N}$ & 7 & 0.191100 & -3.017634 & 0.209712 \\
\hline $\mathrm{C}$ & 6 & 1.538581 & -2.618449 & 0.169265 \\
\hline $\mathrm{C}$ & 6 & 2.586136 & 3.063515 & -0.048348 \\
\hline $\mathrm{N}$ & 7 & 1.485653 & 3.927592 & -0.086230 \\
\hline $\mathrm{C}$ & 6 & 0.147820 & 3.525499 & -0.069340 \\
\hline $\mathrm{O}$ & 8 & 2.422675 & -3.444547 & 0.180854 \\
\hline $\mathrm{O}$ & 8 & -2.035592 & -2.558621 & 0.334461 \\
\hline $\mathrm{O}$ & 8 & 3.717047 & 3.545663 & -0.060406 \\
\hline $\mathrm{O}$ & 8 & -0.769562 & 4.322915 & -0.104742 \\
\hline $\mathrm{C}$ & 6 & -0.057949 & -4.468360 & 0.281909 \\
\hline $\mathrm{C}$ & 6 & 1.785055 & 5.368269 & -0.144442 \\
\hline $\mathrm{P}$ & 15 & -3.470917 & -0.236616 & 0.000766 \\
\hline $\mathrm{N}$ & 7 & 4.689854 & 1.075246 & -0.010915 \\
\hline $\mathrm{C}$ & 6 & 5.841057 & 0.212164 & -0.003856 \\
\hline $\mathrm{C}$ & 6 & 6.257033 & -0.403340 & -1.194434 \\
\hline
\end{tabular}




\begin{tabular}{|c|c|c|c|c|}
\hline $\mathrm{C}$ & 6 & 7.399383 & -1.204866 & -1.151995 \\
\hline $\mathrm{C}$ & 6 & 8.129878 & -1.391243 & 0.022417 \\
\hline $\mathrm{C}$ & 6 & 7.691931 & -0.749204 & 1.183019 \\
\hline $\mathrm{C}$ & 6 & 6.555277 & 0.058486 & 1.195167 \\
\hline $\mathrm{C}$ & 6 & 9.381643 & -2.233245 & 0.030927 \\
\hline $\mathrm{C}$ & 6 & 6.110483 & 0.746516 & 2.462778 \\
\hline $\mathrm{C}$ & 6 & 5.510247 & -0.203999 & -2.491143 \\
\hline $\mathrm{C}$ & 6 & -3.770001 & -1.295481 & -1.449699 \\
\hline $\mathrm{C}$ & 6 & -4.659205 & -2.372617 & -1.395411 \\
\hline $\mathrm{C}$ & 6 & -4.895228 & -3.130259 & -2.538667 \\
\hline $\mathrm{C}$ & 6 & -4.243145 & -2.825860 & -3.731551 \\
\hline $\mathrm{C}$ & 6 & -3.345611 & -1.761571 & -3.782765 \\
\hline $\mathrm{C}$ & 6 & -3.106060 & -0.994180 & -2.646057 \\
\hline $\mathrm{C}$ & 6 & -4.133555 & -0.888472 & 1.565655 \\
\hline $\mathrm{C}$ & 6 & -5.522720 & -1.038907 & 1.684863 \\
\hline $\mathrm{C}$ & 6 & -6.070973 & -1.492520 & 2.880556 \\
\hline $\mathrm{C}$ & 6 & -5.244380 & -1.771950 & 3.966856 \\
\hline $\mathrm{C}$ & 6 & -3.866731 & -1.596816 & 3.857904 \\
\hline $\mathrm{C}$ & 6 & -3.307928 & -1.162135 & 2.660012 \\
\hline $\mathrm{C}$ & 6 & -4.414552 & 1.309332 & -0.259930 \\
\hline $\mathrm{C}$ & 6 & -4.657517 & 2.148736 & 0.839639 \\
\hline $\mathrm{C}$ & 6 & -5.350996 & 3.340829 & 0.667662 \\
\hline $\mathrm{C}$ & 6 & -5.816016 & 3.703792 & -0.595709 \\
\hline C & 6 & -5.587861 & 2.870683 & -1.686968 \\
\hline $\mathrm{C}$ & 6 & -4.888800 & 1.676677 & -1.525293 \\
\hline
\end{tabular}

Rotational constants (GHZ): $\quad 0.0937432 \quad 0.0346666 \quad 0.0303824$ Standard basis: 6-311+G(d,p) (5D, 7F) nuclear repulsion energy $\quad 6749.0964517430$ Hartrees 
Table S6: Theoretical calculation details of $4^{\cdot \pm}$ :

\begin{tabular}{|c|c|c|c|c|}
\hline \multirow{2}{*}{$\begin{array}{l}\text { Center } \\
\text { Number }\end{array}$} & \multirow{2}{*}{$\begin{array}{l}\text { Atomic } \\
\text { Number }\end{array}$} & \multicolumn{3}{|c|}{ Coordinates (Angstroms) } \\
\hline & & $\mathrm{X}$ & $\mathrm{Y}$ & $\mathrm{Z}$ \\
\hline $\mathrm{C}$ & 6 & 3.091440 & -0.762403 & 0.109750 \\
\hline $\mathrm{C}$ & 6 & 3.421082 & 0.600308 & 0.001551 \\
\hline $\mathrm{C}$ & 6 & 2.356643 & 1.566041 & -0.026226 \\
\hline $\mathrm{C}$ & 6 & 1.015562 & 1.132611 & 0.019315 \\
\hline $\mathrm{C}$ & 6 & 0.701261 & -0.258874 & 0.109610 \\
\hline $\mathrm{C}$ & 6 & 1.765930 & -1.187230 & 0.157037 \\
\hline $\mathrm{C}$ & 6 & -0.060057 & 2.058411 & -0.029425 \\
\hline $\mathrm{C}$ & 6 & -1.387126 & 1.616167 & -0.008443 \\
\hline $\mathrm{C}$ & 6 & -1.709475 & 0.266565 & 0.094950 \\
\hline $\mathrm{C}$ & 6 & -0.645106 & -0.693765 & 0.162107 \\
\hline $\mathrm{C}$ & 6 & -0.940576 & -2.095782 & 0.293575 \\
\hline $\mathrm{N}$ & 7 & 0.126728 & -2.989236 & 0.316957 \\
\hline $\mathrm{C}$ & 6 & 1.484390 & -2.624717 & 0.252968 \\
\hline $\mathrm{C}$ & 6 & 2.631473 & 2.997298 & -0.080202 \\
\hline $\mathrm{N}$ & 7 & 1.542126 & 3.873054 & -0.135795 \\
\hline $\mathrm{C}$ & 6 & 0.187246 & 3.495181 & -0.118675 \\
\hline $\mathrm{O}$ & 8 & 2.346297 & -3.492921 & 0.281121 \\
\hline $\mathrm{O}$ & 8 & -2.117239 & -2.498290 & 0.391568 \\
\hline $\mathrm{O}$ & 8 & 3.769467 & 3.486725 & -0.078465 \\
\hline $\mathrm{O}$ & 8 & -0.703157 & 4.336215 & -0.171437 \\
\hline $\mathrm{C}$ & 6 & -0.153047 & -4.424049 & 0.427401 \\
\hline $\mathrm{C}$ & 6 & 1.861649 & 5.302647 & -0.204607 \\
\hline $\mathrm{P}$ & 15 & -3.443077 & -0.222331 & 0.014023 \\
\hline $\mathrm{N}$ & 7 & 4.719332 & 1.013806 & -0.075774 \\
\hline $\mathrm{C}$ & 6 & 5.876444 & 0.182611 & -0.047317 \\
\hline $\mathrm{C}$ & 6 & 6.213378 & -0.618694 & -1.150482 \\
\hline
\end{tabular}




\begin{tabular}{|c|c|c|c|c|}
\hline $\mathrm{C}$ & 6 & 7.377105 & -1.390668 & -1.080474 \\
\hline $\mathrm{C}$ & 6 & 8.215158 & -1.369447 & 0.032099 \\
\hline $\mathrm{C}$ & 6 & 7.866034 & -0.543680 & 1.103934 \\
\hline $\mathrm{C}$ & 6 & 6.709638 & 0.232937 & 1.086660 \\
\hline $\mathrm{C}$ & 6 & 9.480509 & -2.192629 & 0.074194 \\
\hline $\mathrm{C}$ & 6 & 6.350356 & 1.108301 & 2.262464 \\
\hline $\mathrm{C}$ & 6 & 5.363819 & -0.643342 & -2.396374 \\
\hline $\mathrm{C}$ & 6 & -3.785694 & -1.286229 & -1.431006 \\
\hline $\mathrm{C}$ & 6 & -4.728006 & -2.316926 & -1.390070 \\
\hline $\mathrm{C}$ & 6 & -4.972847 & -3.077008 & -2.529475 \\
\hline $\mathrm{C}$ & 6 & -4.275735 & -2.821953 & -3.708990 \\
\hline $\mathrm{C}$ & 6 & -3.324959 & -1.805356 & -3.746504 \\
\hline $\mathrm{C}$ & 6 & -3.077157 & -1.036550 & -2.611584 \\
\hline $\mathrm{C}$ & 6 & -4.180138 & -0.847302 & 1.567602 \\
\hline $\mathrm{C}$ & 6 & -5.574112 & -0.929115 & 1.678503 \\
\hline $\mathrm{C}$ & 6 & -6.156002 & -1.357745 & 2.868660 \\
\hline $\mathrm{C}$ & 6 & -5.353719 & -1.679721 & 3.960745 \\
\hline $\mathrm{C}$ & 6 & -3.968166 & -1.573696 & 3.860504 \\
\hline $\mathrm{C}$ & 6 & -3.379019 & -1.166907 & 2.667201 \\
\hline $\mathrm{C}$ & 6 & -4.410955 & 1.317419 & -0.276268 \\
\hline $\mathrm{C}$ & 6 & -4.626432 & 2.196990 & 0.795620 \\
\hline $\mathrm{C}$ & 6 & -5.325533 & 3.383117 & 0.602479 \\
\hline $\mathrm{C}$ & 6 & -5.827656 & 3.701879 & -0.657942 \\
\hline $\mathrm{C}$ & 6 & -5.627684 & 2.829900 & -1.723633 \\
\hline $\mathrm{C}$ & 6 & -4.921386 & 1.643108 & -1.537497 \\
\hline
\end{tabular}

Rotational constants (GHZ): $\quad 0.0950714 \quad 0.0342422 \quad 0.0300640$ Standard basis: 6-311+G(d,p) (5D, 7F) nuclear repulsion energy $\quad 6747.2990796594$ Hartrees. 


\section{References:}

1. B. A. Jones, A. Facchetti, T. J. Marks and M. R. Wasielewski, Chem. Mater., 2007, 19, 2703.

2. M. Sasikumar, Y. V. Suseela, T. Govindaraju, Asian J. Org. Chem. 2013, 2, 779.

3. D. Becke, J. Chem. Phys., 1993, 98, 5648.

4. C. Lee, W. yang, R. G. Parr, Phys. Rev. B, 1988, 37, 785.

5. Gaussian 09, Revision D.01, M. J. Frisch, G. W. Trucks, H. B. Schlegel, G. E. Scuseria, M. A. Rob, J. R., Cheeseman, G. Scalmani, V. Barone, B., Mennucci, G. A. Petersson, H. Nakatsuji, M. Li, X. Caricato, H. P. Hratchian, A. F. Izmaylov, J. Bloino, G. Zheng, J. L. Sonnenberg, M. Hada, M. Ehara, K. Toyota, R. Fukuda, J. Hasegawa, M. Ishida, T. Nakajima, Y. Honda, O. Kitao, H. Nakai, T. Vreven, Jr. J. A. Montgomery, J. E. Peralta, F. Ogliaro, M. Bearpark, J. J. Heyd, E. Brothers, K. N. Kudin, V. N. Staroverov, R. Kobayashi, J. Normand, K. Raghavachari, A. Rendell, J. C. Burant, S. S. Iyengar, J. Tomasi, M. Cossi, N. Rega, J. M. Millam, M. klene, J. E. Knox, J. B. Cross, V. Bakken, C. Adamo, J. Jaramillo, R. Gomperts, R. E. Startmann, O. Yazyev, A. J. Austin, R. Cammi, C. Pomelli, J. W. Ochterski, R. L. Martin, K. Morokuma, V. G. Zakrzewski, G. A. Voth, P. Salvador, J. J. Dannenberg, S. Dapprich, A. D. Daniels, Ö. Farkas, J. B. Foresman, J. V. Ortiz, J. Cioslowski, D. J. Fox, Gaussian, Inc., Wallingford CT, 2009. 